\title{
Promoting Smetana's Bartered Bride (Prodaná nevěsta) in Paris
}

\section{Katerina Viktorová}

Abstract: The Bartered Bride had to take a thorny path to reach the stage in Paris. Sixty years passed between the first attempts while Smetana was still living and the premiere at the Opéra-Comique. There were many people from the spheres of culture and politics involved in promoting the performing of The Bartered Bride in Paris, the most important centre of opera in those days. Foremost among them was Princess Pauline von Metternich, the French baritone Victor Maurel who held the first fragmentary performance of the opera in 1897 in his salon with soloists from the Opéra-Comique, the director of the National Theatre František A. Šubert, the French conductor Charles Lamoureux, the physician and translator Raoul Blondel, the violinist Jan Kubelík, the theatre director Gabriel Astruc, and the wife of the Czechoslovak ambassador in Paris Pavla Osuská. However, the Paris premiere of The Bartered Bride in 1928 did not earn the opera a more permanent place at that city's theatres.

Key words: Prodaná nevěsta, The Bartered Bride, Bedřich Smetana, Pauline von Metternich, Victor Maurel, František A. Šubert, Raoul Blondel, Opéra-Comique

"Smetana unfortunately lacks [...] the external qualities of polish, elegance, what one might call 'clinquant', that suit Paris. They will be interested in him as a geographical phenomenon much later in series of historical concerts. [...] And the operas, too, conceived based on subject matter that Parisians will call old fashioned without hesitation, and librettos that are know to be deficient, with a single exception!! We should add that the extraordinary libretto of The Bartered Bride is based on subject matter that, however pleasant, would be perceived as a humiliation by the courageous snobs who make up most of the devotees of Monna Vanna, Pelléas, and Ariane et Barbe-bleu if they had to take an interest in it. These days there is hardly any theatre attempting to produce anything of the kind unless they are

This work was financially supported by the Ministry of Culture of the Czech Republic (DKRVO 2019-2023/22.III.b, National Museum, 00023272).

The author wishes to thank everyone who helped her with work on this study: Magdalena Pechlátová collaborated significantly with the author on translating excerpts from letters and the period press from French into Czech; Petra Kulovaná transcribed excerpts from Pauline von Metternich's letters that were written in German using the Kurrent style of handwriting. In the Czech version of this article, all foreign language quotes were translated into Czech by the author unless stated otherwise.

1) Monna Vanna, opera by Henry Février (1909); Pelléas et Mélisande, opera by Claude Debussy (1902); Ariane et Barbe-bleue, opera by Paul Dukas (1907). 
virtually compelled to do so by a surge of public opinion. [...] The Bartered Bride would have been a brilliant success in France thirty years ago; today, I fear, given how the conditions have changed, it may be too late for that!"2

These words were written in 1909 by the music critic William Ritter, author of the first French book about Smetana and his works, who placed Smetana between Berlioz and Wagner. ${ }^{3}$ Just from the quoted lines, one gets the sense of how hard it was to promote Smetana's Bartered Bride on stage in Paris. Thanks to the overture, which was often played at concerts, the work was not totally unknown to the French public. At the end of the 1860s, Smetana himself made the first attempts to promote the opera in Paris, which was regarded as the world's operatic capital. At the recommendation of František Ladislav Rieger, who had been trying to lay the groundwork for performances of certain operas by Czech composers in Paris in the 1860s, and of Raffaele Vitali, ${ }^{4}$ Smetana wrote to the Parisian theatrical agent Adolph Giacomelli, ${ }^{5}$ introducing him to the opera and sending him the performance material. "The melodies might have the magic of a novelty for Paris and could provoke greater interest than usual because they come from the most inexhaustible treasury of the character of the Czech nationality, which is still little known around the world, and the rhythms and melodies of this music go their own way. [...] It remains up to you to decide on the Parisian theatre with which this Czech bride is to be betrothed in accordance with refined French tastes." When plans for a French translation fell through, ${ }^{8}$ Smetana had the full score and

2) RITTER, William: Frncouzi [!] a Smetana (The French and Smetana), Hudební revue (Musical Revue), vol. 2, 1909, no. 5, pp. 285-286 (hereinafter RITTER 1909).

3) RITTER, William: Smetana, Editions Alcan, collection Les Maitres de la Musique, Paris 1907 (hereinafter RITTER 1907).

4) Raffaele Vitali (1815-1896), conductor at the Théâtre Italien in Paris.

5) Adolphe Giacomelli (1825-1893) was a publisher of musical and theatrical journals and a Parisian theatre agent.

6) See the entry dated 14 August in Diárové zápisky Bedřicha Smetany 1869 (Diary Entries of Bedřich Smetana for 1869): "Opera ,Prodanou nevěsta' zasláná do Pařiše." ("The opera 'The Bartered Bride’ was sent to Paris.”) Autograph, in: Kalendář Koruny české na obyčejný rok 1869 (Calendar of the Czech Crown for the Calendar Year 1969), Ed. Grégr, Praha [1868] (National Museum - Czech Museum of Music - Bedřich Smetana Museum, hereinafter NM-MBS, S 217/1109; hereinafter in the footnotes: Diářové zápisky Bedricha Smetany 1869).

7) "Les mélodies pourrient avoir pour Paris les charme de la nouveauté et inspirer un plus grand intérets qu'autrefois, parcequ'elles sont pleinment puisées de la source impuisible - encore peu connue - de la maniére du peuple tchèque, - qui vont dans la Rythmique et melodique leur propre chemin du sentiment. [...] À quel théatre de Paris cette fiancée tchèque doit être mariée au gout français purifié - cela reste naturellement votre resolution." Smetana to Giacomelli, draft of a letter dated 14 Aug. 1869, [Prague]. The fair copy of the letter, apparently written in French, is now lost. The French draft of the letter (made by translating Smetana's German draft) has been preserved in a copy made by Zdeněk Nejedlý with the comment that the original, written in someone else's hand, was in the possession of Zdenka Heydušková (MÚA AV ČR, Z. Nejedlý collection, cart. 19, XIV/4). In: MOJŽÍŠOVÁ, Olga - POSPÍŠIL, Milan - VOJTĚŠKOVÁ, Jana - KROUPA, Jiř́ K.: Bedřich Smetana. Korespondence II (1863-1874), Národní muzeum and Nadace pro dějiny kultury ve střední Evropě (Association for Central European Cultural Studies) in cooperation with KLP - Koniasch Latin Press s.r.o., Praha 2020, pp. 262-263 (hereinafter MOJŽÍŠOVÁ - POSPÍŠIL - VOJTĚŠKOVÁ - KROUPA). Giacomelli’s response to Smetana's letter is not known.

8) Smetana had already informed Isaac Philip Valentin about work on a French translation in a letter dated 13 Feb. 1868. It is not known why the translation was not ultimately realised. See MOJŽÍŠOVÁ - POSPÍŠIL VOJTĚŠKOVÁ - KROUPA, op. cit. in footnote no. 7, pp. 193-195. 
piano vocal score of The Bartered Bride copied at his own expense, and he sent the libretto to Emanuel Züngel to translate it into German, ${ }^{9}$ but the materials he sent were lost in Paris. ${ }^{10}$

\section{A great promoter of Smetana's music}

There the matter lay nearly dormant until it was fully and systematically taken up by a great promoter of Smetana's music, Princess Pauline von Metternich. ${ }^{11}$ She adored music in general, and once she had "adopted" a composer, she would promote him tirelessly. Her enthusiasm for Smetana's opera and her strenuous efforts to have it performed in Paris were noted by František Adolf Šubert in his book of memoirs. "Today, even outside of Bohemia there are thousands of admirers of the great master, but I do not know anyone with such a fiery passion for the genius and his 'Bartered Bride' or who has worked so persistently for the spread of his fame as Princess Metternich. This has to do with the princess's temperament, with her boundless reservoir of fresh energy, and with the unparalleled tenacity with which she pursues whatever goal has enflamed her mind and spirit." ${ }^{2}$ She saw The Bartered Bride for the first time as the honorary chairwoman of the exhibition committee in 1892 at the International Exhibition of Music and Theatre in Vienna presented by the ensemble of Prague's National Theatre. It was success in Vienna that brought the opera international recognition and opened the door to stages in Europe and eventually worldwide. ${ }^{13}$ Less than a year later, on 2 April 1893, the opera was produced in a German translation by Max Kalbeck at the Theater an der Wien, ${ }^{14}$ and more productions soon followed. A French newspaper reported about that performance and recommended that the opera soon be produced in Paris as well.

9) See Diářové zápisky Bedřicha Smetany 1869, op. cit. in footnote no. 6.

10) Concerning the fate of the parcel of performance materials for The Bartered Bride, see Terezie Bubeníčková to Smetana, letter dated 8 June 1870. See MOJŽÍŠOVÁ - POSPÍŠIL - VOJTĚŠKOVÁ - KROUPA, op. cit. in footnote no. 7, pp. 284-285. Unfortunately, the parcel had not been franked, and theatrical agents did not pay postage for packages. The score was being held in Paris at the Ministry of the Interior, where it was necessary to pay 50-60 francs. Bubeníčková asked her friend Louis Léger to take care of the parcel, and she sent him a voucher for 60 francs to pay for it. The ultimate fate of the material is not known, and it is now lost.

11) Pauline von Metternich-Sándor (1836-1921), the wife of the Austrian ambassador in Paris, came from the Hungarian noble family of Sándor de Szlavnicza. The ambassador's palace in the 1860 s was a gathering place for the cream of France's artistic milieu at the time. In order to pursue her goals, she was ably to rely on her contacts at the imperial court of Napoleon III and in diplomatic and aristocratic circles. After the death of her husband Prince Richard Metternich in 1895, she added her maiden name from her Hungarian family to her princely name. Among other things, she was responsible for the first performance of Wagner's Tannhäuser in 1861 at the Opéra Le Peletier.

12) ŠUBERT, František Adolf: Kněžna Pavlína z Metternich-Sándorů a Bedřich Smetana (Princess Pauline von Metternich-Sándor and Bedřich Smetana), in: Moje vzpomínky I. Z uplynulých dob, tiskem a nákladem České grafické společnosti "Unie" (My Memoirs from Past Times, printed and published by the Czech graphics company "Unie"), Praha 1902, p. 55 (hereinafter ŠUBERT).

13) Performances of The Bartered Bride around the world were surveyed by the exhibition The Bride Bartered Abroad at the NM-MBS (by Kateřina Viktorová, 6 March 2019 - 4 Oct. 2021).

14) For more details, see REITTEREROVÁ, Vlasta - REITTERER, Hubert: Vier Dutzend rothe Strümpfe... Zur Rezeptionsgeschichte der "Verkauften Braut" von Bedřich Smetana in Wien am Ende des 19. Jahrhunderts, Verlag der Österreichischen Akademie der Wissenschaften, Wien 2004; REITTEREROVÁ, Vlasta: Dvě první vídeňské Prodané nevěsty a jejich představitelé (Theater an der Wien 1893, Hofoper 1896) / The First Two Viennese Productions of Prodaná nevěsta and Their Performers (Theater an der Wien 1893, Hofoper 1896), Musicalia, vol. 8, 2016, nos. 1-2, pp. 22-36 (Czech version), pp. 37-58 (English version). 
"The real political event of the last 14 days - who would have thought? - has been the performance of a Czech opera at the Theater an der Wien. [...] It is incredible! The work in question, The Bartered Bride by the composer Smetana, is a comic opera that is adorable in every respect. The libretto is nothing much, but there is a nice role for basso buffo, a rustic matchmaker for village weddings. [...] The plot is a bit childish, but it is brought to life by delightful music that one might say seems to have gushed forth freshly from Mozart while, at the same time, overflowing with Slavonic melodies of a peculiar charm. Besides that, there are very pretty dances, and the Czech ethnic costumes are a treat for the eyes. Take notice, Mr. Carvalho!n It seems to me that a skilful adaptation of The Bartered Bride would please Parisians greatly, especially if they take political sympathies into account. In any case, it is a little masterpiece, although it has taken nearly 30 years for the world to take notice of it."16

Metternich was determined to use all of her political and social influence to promote the performing of The Bartered Bride at the Opéra-Comique. ${ }^{17}$ She also began negotiations

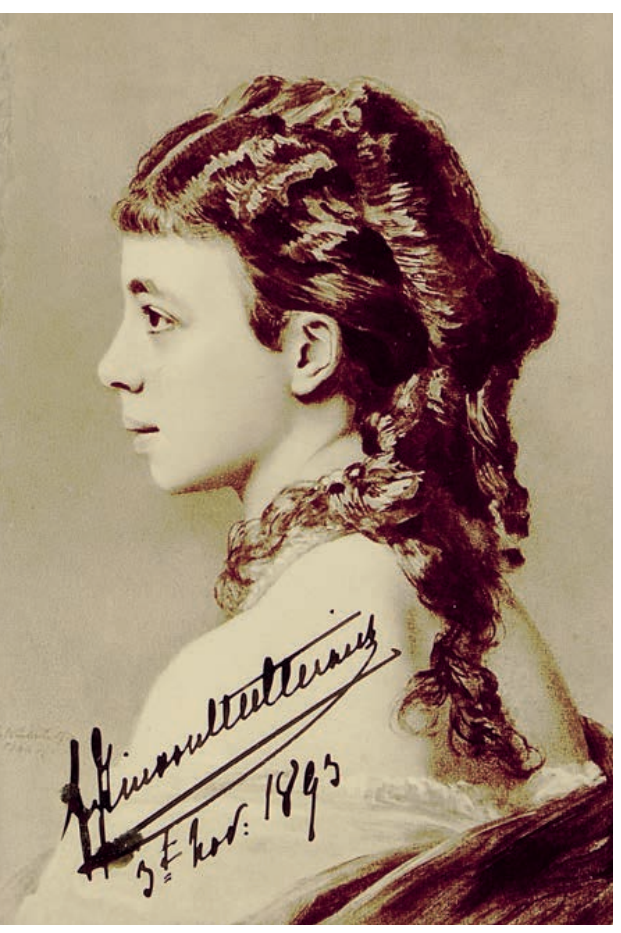

Princess Pauline von Metternich-Sándor (1836-1921) / Kněžna

Paulina Metternichová-Sándorová (1836-1921) Photograph, Victor Angerer, Vienna, 1860s /

Fotografie, Victor Angerer, Vídeň, 60. léta 19. století NM-MBS inv. no. / inv. č. 2735

15) Léon Carvalho (1825-1897) was a French impresario and stage director and the executive director of Paris's Opéra-Comique from 1876 to 1887 and from 1891 to 1897.

16) 'Le véritable événement politique de la quinzaine - qui l'eût jamais cru? - c'est la représentation d’un opéra tchèque au Théâtre an der Wien. [...] C'est à ne pas y croire! La Fiancée vendue, du compositeur Smetana, dont il s'agit, est un opéra-comique en tous points charmant. Le livret ne vaut pas grand'chose. Mais il y a un joli rôle pour une basse bouffe, celui d'un paysan entremetteur de mariages champêtres. [...] L'intrique, on le voit, est tant soit peu enfantine. Mais tout cela est animé par une musique bien délicieuse, comme qui dirait du Mozart fraîchement éclos et noyé dans des mélodies slaves d’une saveur particulière. Avec cela, il y a des ballets très jolis, et les costumes nationaux de la Bohême réjouissent l'oeil. Avis à M. Carvalho. Il me semble que la Fiancée vendue, habilement adaptée, devrait plaire beaucoup aux Parisiens, étant données au surplus les sympathies politiques. Dans tous les cas, c'est un petit chef-d'oeuvre en son genre, bien que le monde ait mis trente ans à s'en apercevoir." VOGT, Walter: Courrier de Vienne, Le Figaro, vol. 39, 12 April 1893, no. 102, p. 4.

17) The Opéra-Comique (Théâtre de l'Opéra-Comique) was established in 1801 by the merger of Paris's two most important comic theatres, the Théâtre Feydeau and the Salle Favart. It performed the comic opera genre, which had been very popular in Paris already since the $18^{\text {th }}$ century. The present-day building was opened in 1898 on a square named after the composer F. A. Boieldieu. In the second half of the $19^{\text {th }}$ century, the Opéra-Comique was a major competitor with the Opéra Garnier, and it was the site of the premieres of many operas by popular composers. It was at the original building, which later burned down, that Bizet's 
with the executive director of Prague's National Theatre František A. Šubert, who also took many steps in this matter. His work-related correspondence contains letters with many persons who were committed to introducing The Bartered Bride to the Paris public. ${ }^{18}$ Pauline von Metternich attended a performance of The Bartered Bride at Prague's National Theatre on November 1893. 19 "I have told Mr. Carvalho so much that is good and beautiful about the Prague performance that if he does not do as we ask, he does not understand his own interests. If his response is negative, I shall turn to someone else, namely to Countess Greffulhe, ${ }^{20}$ who is the president of the 'grandes auditions musicales,' where each year leading artists perform an opera that is not yet known to the Parisian public."21 However, the matter did not turn out the way Metternich had expected. It was the important French baritone Victor Maurel ${ }^{22}$ who became enthusiastic about her idea and wanted the role of Kecal for himself. "I am not forgetting about Smetana, and I want to ask you to send the score of 'The Bartered Bride' promptly to Mr. Victor Maurel at the address 10 rue Lesueur in Paris because the famous baritone asked me for it recently and we, viribus unitis, are committed to this, so that Smetana's splendid opera can finally get performed here. I would have no objection to having it announced through the Czech and Prague newspapers that we are making serious efforts to have the performance take place because that is how to get the

Carmen was first performed in 1875, and in ca. 1900 and the years that followed there were premieres of such operas as Charpentier's Louise, Debussy's Pelléas et Mélisande, and Dukas's Ariane et Barbe-bleue.

18) For example, he was in contact with the director of Paris's Théâtre du Vaudeville Albert Carré, the director of Paris's Opéra-Comique Léon Carvalho, the director of the Flemish Theatre in Anvers Edward Keurvels, the organisers of the World Exhibition in Paris, the editor-in-chief of the Journal musical Baudouin la Londre, the editor-in-chief of the newspaper Gil Blas Albert de Lapeyrouse, the editor-in-chief of the weekly journal Le Ménestrel Oscar Berggruen, and the publishing company Choudens, which published French operas of the $19^{\text {th }}$ century and which was Šubert recommendation to obtain the publishing and performance rights for France and Belgium for these operas. See the National Archives, collection of the National Theatre Archive (hereinafter NA, AND collection), D 183-D 201, and D 232/78-81; and Literární archiv Památníku národního písemnictví (Literary Archive of the Museum of Czech Literature, hereinafter PNP LA), F. A. Šubert collection (not processed).

19) ŠUBERT, op. cit. in footnote no. 12, p. 56.

20) Élisabeth Greffulhe (1860-1952) was a patron of science and the arts. In 1890 she established the Société des grandes musicales. She organised chamber music concerts and theatrical performances. In 1890, for example, she had Berlioz's opera Béatrice et Bénédict performed at the Théâtre de l'Odéon, and she was responsible for the first Paris performance of Richard Wagner's Tristan und Isolde in October 1899. She was known as the queen of the salons of the Faubourg Saint-Germain in Paris. She inspired many artists - she became the model for the character of the Duchess de Guermantes in Marcel Proust's $\mathcal{A}$ la recherche du temps perdu, and Gabriel Fauré's Pavane, op. 50, is a musical portrayal of the countess.

21) "Ich habe Herrn Carvalho so viel Schönes und Gutes über die Vorstellung in Prag erzählt daß wenn er uns kein Gehör schenkt er seine Interessen nicht versteht. In dem Falle einer ablehnenden Antwort werde ich mich anderswo hinwenden und das nämlich an die Gräfin Greffulhe welche Präsidentin der, grandes auditions musicales' ist und alljährlich eine dem Pariser Publikum unbekannte Oper durch Künstler allerersten Ranges aufführen läßt.” Metternich to Šubert, letter dated 10 Nov. 1893, Plasy. PNP LA, F. A. Šubert collection.

22) Victor Maurel (1848-1923) sang the roles of Iago in Otello (1887) and of Falstaff (1893) at the world premieres of the Verdi operas. Among his most prominent roles were Hamlet, Don Giovanni, Rigoletto, and Faust. Already in 1869 he was engaged at Milan's La Scala, and at London's Covent Garden he appeared in Wagner's Lohengrin, Tannhäuser, and Derfliegende Holländer. He made appearances at the Metropolitan Opera in New York and in Paris at the Opera and at the Opéra-Comique. 
matter into the French journals, and as soon as we win over the press, we shall have won, and Smetana will be just as triumphant in Paris as everywhere else! [...] P. S. Victor Maurel is now regarded as France's leading baritone, and rightly so."23

A French critic published a lengthy article about Smetana, in which the author claimed that not only all over Germany, "all of the critics are interested in him, special performances of his works are being organised, music dealers are selling portraits of him [...]. So far, France alone is doing without Smetana. But I think it is just a matter of months."24 For a while it looked as if things really were headed towards a performance of The Bartered Bride. It was hinted at by reports in both the Czech and the French press. For example, it was reported that the opera would be produced in Paris and in Milan and that on that occasion Josef Weinberger ${ }^{25}$ would be printing the score of the opera in French and Italian translations. ${ }^{26}$ A Parisian daily newspaper also called for The Bartered Bride to be performed during the coming season at the Opéra-Comique. "We are hearing that serious consideration is being given to the producing of The Bartered Bride next winter at the Opéra-Comique. She who was once the protector [Metternich] of Tannhäuser in this country [...] shall be overjoyed by this. [...] It is our

23) "Ich vergesse nicht Smetana und komme Sie zu bitten umgehends die Partitur der ,Verkauften Braut' an Herrn Victor Maurel 10. Rue Lesueur in Paris schicken zu wollen da dieser berühmte Bariton mich neulich darum aufsuchte und wir viribus unitis trachten wollen Smetana's köstliche Oper endlich hierselbst zur Aufführung zu bringen. Ich habe nichts dagegen wenn Sie in den böhmischen und überhaupt in den Prager Zeitungen bekannt geben lassen daß wir uns hier ernstlich einsetzen um eine solche Aufführung zu ermöglichen denn dadurch kommt die Geschichte in die französischen Journale und wenn wir uns einmal die Presse für uns haben dann haben wir gewonnenes Spiel und Smetana triumphiert in Paris so wie überall! [...] Victor Maurel gilt jetzt, und mit Recht als der erste Bariton Frankreichs." Metternich to Šubert, letter dated 10 June 1896, Paris. The original is kept at the PNP LA, F. A. Šubert collection.

24) 'tous les critiques s'occupent de lui, on organise des exécutions spéciales de ses oeuvres; les marchands de musique vendent son portrait; [...] La France seule, pour le moment, se passe de Smetana. Mais j'imagine que ce n'est plus qu'une affaire de mois;" Un nouveau génie musical. Frédéric Smetana, Revue Bleue, la revue politique et littéraire, vol. 24, 14 April 1894, no. 15, p. 469.

25) Josef Weinberger (1855-1928) was a Viennese music publisher who was authorised by Smetana's heirs as the agent for his works.

26) Národní listy, vol. 35, 9 May 1895, no. 127, p. 3. 
sincere wish that Paris, [...] the former capital city of the arts yearning to regain its importance, shall wait no longer than until next season to produce The Bartered Bride. That shall be the loveliest of all evenings - beautiful and touching in all respects."27 The producing of the opera was also confirmed by other newspapers, which mentioned The Bartered Bride together with Massenet's Cendrillon (Cinderella), Mozart's Don Giovanni, Wagner's Der fliegende Holländer, and the operas Pêcheurs de Saint-Jean by Charles M. Widor, Kermaria by Camille Erlanger, and Dalila or Vanina by Émile Paladilhe as new premieres for the coming season of the Opéra-Comique. ${ }^{28}$ This information was also apparently the basis of reports in the Czech press as well, which announced that "The Bartered Bride has been accepted definitively for a production at the Opéra-Comique in the immediate future."29 There were, however, others who called this into question: "Contrary to the assertions of many journals, we must state with severe regret that the performing of Smetana's 'Bartered Bride' in Paris has become very doubtful. This despite all of the zealous efforts of Princess Pauline von Metternich, who has taken this up this most pleasing, prosperous of sports as her pastime. What are the obstacles? The administration of the Grand Opera of lyric theatre ${ }^{30}$ supposedly claims that a musical work that crosses over into the field of comic opera, and yes even into the operetta genre, cannot be played on its stage at all as a matter of principle (!), so it is relegating 'The Bartered Bride' to Paris's Opéra-Comique. But in turn the Opéra-Comique says it cannot perform 'The Bartered Bride' supposedly because it does not have a ballet troupe. Is this true or just an excuse?"31

\section{The French press about The Bartered Bride in reaction to its premiere at the Vienna Court Opera}

The premiere of The Bartered Bride at the Court Opera in Vienna on 4 October 1896 generated increased interest of the French press in the work. ${ }^{32}$ Besides reviewing the Vienna premiere, the articles also expressed the wish that now that the opera had been produced

27) 'Il nous revient qu'il est grandement question de donner, l'hiver prochain, la Fiancée vendue à l’OpéraComique. Celle qui fut chez nous, autrefois, la protectrice de Tannhoeuser, [...] qu'elle n'en ait la joie. [...] Nous faisons des voeux sincères pour que Paris, [...] ancienne capitale de l'art soucieuse de reconquérir son rang, n'attende pas au delà de la saison prochaine qu'on fasse paraitre à ses yeux la Fiancée vendue. Ce sera une soirée belle entre toutes - belle et touchante à tous égards." UN MUSICIEN: Un chef d'oeuvre bohémien à Paris, Le Gaulois, vol. 30, 29 July 1896, no. 5376, p. 1.

28) La Liberté, vol. 31, 29 Aug. 1896, no. 11604, p. 4. The same report was also published in the newspaper Le Matin, vol. 13, 28 Aug. 1896, no. 4565, p. 3.

29) Dalibor, vol. 18, 3 Oct. 1896, no. 40, p. 318.

30) Opéra Garnier (also called the Palais Garnier).

31) Listy z Prahy, Plzeňský Obzor. Svobodomyslný list pro Plzeň a západní Čechy (Papers from Prague, Pilsen Horizon. A freethinking journal for Pilsen and Western Bohemia), vol. 5, 18 Nov. 1896, no. 93, p. 1.

32) The Court Opera (Hofoper) was a bit slow in producing The Bartered Bride. In fact, it managed to produce two other Smetana operas first: Hubička (The Kiss, 27 Feb. 1894) and Tajemství (The Secret, 27 March 1895). The premiere of The Bartered Bride at the Court Opera did not take place until three years after the successful performance at the Theater an der Wien. 
at nearly all of Germany's theatres, ${ }^{33}$ the time had come for it to be taken up by one of the theatres in Paris. "There is life flowing in the superb playing of the orchestra that is entirely absent in our two Parisian opera theatres [Opéra Garnier and the Opéra-Comique]. These Viennese fellows are the embodiment of music! [...] I got no small amount of satisfaction from seeing something other than the foot-dragging on which our Opera has a monopoly. I hope that The Bartered Bride will also get played in Paris soon."34 This article was also written under the impression of the same reviewer's attendance of a performance of The Bartered Bride when visiting Prague. "Mr. Salvayre was pleased by the performance(s) [he attended three different operas in total] in Prague, and in a letter he sent me, he emphasised the big difference that prevails between the opinions at Vienna's Court Opera and at the Czech National Theatre. It is beyond my comprehension why the stage director in Vienna did not try to come as close as possible to the concept used at the Prague theatre and did not conceive scenery of a more typically ethnic character! [...] According to Salvayre, Carvalho would supposedly perform 'The Bartered Bride' badly because he lacks the forces in many respects. For the role of Kecal he would have only Fugère... His chorus is wretched, and the ballet is constantly being criticised! Now they want to establish a 'theatre universel', and they supposedly already have the funds in place - the participants promised me that 'The Bartered Bride' will be the first thing they perform! Let us not wait until 1900 [the year of the World Exhibition] ..., after all, the Czech National Theatre might come to Paris, and it should do so!'35

We learn about the effect of Smetana's opera on French critics from another reaction to the premiere at Vienna's Court Opera. "I left the opera [...] enchanted, pleased, full of affectionate admiration for the Czech genius, in a word, a convinced Smetana follower [...] and there are plenty of them - not only in Bohemia and Austria - who are not afraid to compare him with Mozart. Maybe that is excessive [...] that little village girl [The Bartered Bride] is spreading Smetana's name all over Europe. [...] Mr. Carvalho, who has a generous heart, should not refuse her his hospitality. [...] In the genre and tradition of comic opera, I cannot imagine

33) During the 1890s, The Bartered Bride was performed in many European cities, and especially in Germanspeaking territory: Berlin, Frankfurt am Main, Dresden, Aachen, Leipzig, Cologne, Bremen, Munich, Hamburg. 34) "Dans la belle exécution de l’orchestre circule la vie qui manque absolument, je le maintiens, dans nos deux théâtres lyriques parisiens. Ah! ces coquins de Viennois sont la musique même! [...] ce n’a pas été, pour moi, une mince satisfaction de voir autre chose que les piétinements sur place dont notre Opéra semble avoir accaparé le monopole. A bientôt, j’espère la Fiancée vendue à Paris." SALVAYRE, G. B.: À l'Opéra Imperial de Vienne. La Fiancée vendue, Gil Blas, vol. 18, 10 Nov. 1896, no. 6203, p. [3].

35) "Herr Salvayre war über die Aufführung in Prag (die Aufführungen) sehr entzückt und hat den gewaltigen Unterschied welcher zwischen der Auffassung in der Wiener Hofoper und im böhmischen Nationaltheater ganz besonders in seinem Briefe an mich hervorgehoben. Mir bleibt es unerklärlich daß der Régisseur in Wien nicht getrachtet hat der Auffassung im Prager Theater möglichst nahe zu kommen und die Mise en scène typischer, nationaler zu gestalten! [...] Carvalho würde nach Salvayre's Ansicht die ,Verkaufte Braut' schlecht aufführen indem ihm die Kräfte in vielfacher Beziehung fehlen. Er hätte nur Fugère für die Rolle des Kecal... Der Chor ist bei ihm miserabel und das Ballet-corps unter h.der Kritik! Man will jetzt ein ,theatre universel' gründen und sollen die Kapitalien schon da sein - die Theilnehmer haben mir die Zusage gemacht im allererster Reihe die ,Prodaná nevesta' aufgeführen! Bis zum Jahre 1900 warten wir nicht ... jedenfalls könnte und sollte darin das böhmische Nationaltheater in Paris sich zeigen!" Metternich to Šubert, letter dated 6 Dec. 1896, Schoppenwihr. PNP LA, F. A. Šubert collection. Ultimately, the National Theatre was not invited to Paris for the 1900 World Exhibition. 
a better opera than The Bride. [...] The role of the stuttering Vašek is perfect; the scene where Kecal, furiously angry, is hounded by the taunts of the chorus is reminiscent of bits of The Barber of Seville without being the worse for it. The scene of the comedians, the entrance of the principal character, and the seducing of the idiot by Esmeralda are guaranteed to be effective. The festive chorus of villagers, the overture, the drinking men, the dance music that closes Act I and begins Act II; all by itself, this dance, so original with clapping and very striking gestures, will surely be very successful. [...] As far as the question of 'feeling' is concerned, the Paris public, which has always loved melody, will find plenty of wonderful ones here. Even the Wagnerites, if willing, will find a leitmotiv in it: this involves a very tender phrase that is introduced in the overture, then appears in Act I, in the duet of the lovers, and throughout the work [...]. If Mr. Carvalho has the courage to pack his bags and, if he has not already done so, take the first opportunity to go to Vienna or Prague; he will not regret taking the trip. ${ }^{36}$ Metternich and Subert were convinced that this positive press coverage would greatly advance their cause and help convince the director Carvalho finally to open the doors at the Opéra-Comique to The Bartered Bride. The princess also began to negotiate with Smetana's heirs on having the opera translated into French.

\section{A first fragmentary performance of The Bartered Bride in Paris in 1897}

Metternich and Maurel decided to introduce The Bartered Bride to Paris through selected excerpts. "We are now considering having some parts of the opera heard in May or June and holding a big soirée at the Maurels's home for that purpose. [...] at the same time, I am forwarding you a letter from $\mathrm{Mr}$. Nuitter, ${ }^{37}$ which is, as it seems, a translation [of The Bartered Bride] in prose!? ?38 Concerning the performance of fragments of The Bartered Bride and the

36) 'Je suis sorti de l’Opéra, [...] charmé, ravi, plein d’un sorte d'affectueuse admiration pour le doux génie du maître tchèque, en un mot smetanien convaincu. [...] Les partisans de Smetana, - ils sont légion en Bohême et en Autriche, - ne craignent pas de le comparer à Mozart. C'est peut-être beaucoup [...] la petite paysanne [Fiancée vendue] tchèque est en train de promener par toute l'Europe le nom de Smetana [...] M. Carvalho, qui a le cœur généreux, ne saurait lui refuser l'hospitalité. Je ne puis concevoir de pièce qui soit, nieux que la Fiancée, dans le genre et la tradition de l’opéra-comique. [...] Le rôle du bègue Wenzel est parfait; la scène où Kezal, berné, furieux, est poursuivi par les railleries du chœur, rappelle, sans trace d'infériorité, tel ou tel morceau du Barbier de Séville. La scène des saltimbanques, l'annonce du bateleur, chef de la troupe, la présentation des artistes, la séduction du crétin par Esmeralda, sont d’un effet sûr. Le choeur des paysans en fête, à l'ouverture; celui des buveurs, l'air de danse qui termine le premier acte et qui commence le second; cette danse, elle-même, d'un caractère si original, avec des battements de mains et une mimique si expressive, auront un vif succès, cela est certain. [...] Quant à la partie, sentimentale' le public parisien, qui a toujours eu une vieille tendresse pour les mélodies, y en trouvera à foison, et d'exquises. Les wagnériens même, s'ils le veulent, y pourront découvrir un leitmotiv: c'est une phrase délicieuse, qui, préparée dans l'ouverture, apparaît au premier acte, dans le duo des amoureux, et se maintient à travers la pièce [...]. Que M. Carvalho, en conclusion, ait le courage de préparer sa valise, et, au premier moment, s'il ne l'a déjà fait, qu'il coure à Vienne ou à Prague; l'excursion ne lui laissera aucun regret." BOUSQUET, Henri: La "Fiancée vendue" de Smetana a l'Opéra Royal de Vienne, Journal des débats politiques et littéraires, vol. 108, 15 Oct. 1896, no. 288, p. 3.

37) Charles Nuitter (1828-1899) was a French dramatist, librettist, and translator. For example, he translated Weber's Oberon, Verdi's Macbeth and Aida, and Wagner's Der fliegende Holländer, Tannhäuser, and Lohengrin into French.

38) "Wir gedenken nun im Mai oder Juni in Paris einige Sachen aus der Oper zu Gehör bringen zu lassen und zwar soll zu diesem Zwecke eine große Soirée bei Maurel's stattfinden. [...] übersende Ihnen gleichzeitig 
conditions for Maurel's possible subsequent guest appearance in Prague, Šubert engaged in intensive correspondence with the baritone and his wife Anne between 1896 and $1898 .{ }^{39}$ We also get a more detailed look at preparations for the salon performance from Maurel's correspondence to Pauline von Metternich. ${ }^{40}$ The main topics were the casting of individual roles and the French translation of the libretto. That task had not been entrusted to Nuitter by the Viennese agent for Smetana's operas Weinberger. "An important question: the translation. I don't think it would be good to turn to Nuitter, who will take a long time and will not create anything good, as is shown by his Wagner translations. On the other hand, Alfred Ernst would do excellent translations from both a musical and a literary perspective. If you have not yet offered Nuitter anything, it would be better to wait, and as soon as I receive your response, I shall act accordingly and approach Alfred Ernst ${ }^{41}$ afterwards. ${ }^{\prime 22}$ Ultimately, Metternich approached Raoul Blondel. ${ }^{43}$ Blondel did not know Czech, so he was not working from Sabina's text, but from a German translation by Max Kalbeck. "[...] yesterday I had a meeting with Mrs. Maurel and Dr. Blondel, at which a translation into French was read and sung to me. It is outstanding and so typical, both close to the [original] text and appropriate to the music, that all I could do was congratulate Dr. Blondel. I even think his translation is closer to the Czech original than the German!"44

A fragmentary performance of The Bartered Bride took place on 19 June 1897 in a salon of the palatial home of the Maurel family on the rue de Logelbach near Parc Monceau and the

einen Brief Herrn Nuitter's welcher, wie es scheint, eine Übersetzung in Prosa!?” Metternich to Šubert, letter dated 26 March 1897, Paris. PNP LA, F. A. Šubert collection.

39) There were reports in the Czech press about the success of the salon performance of The Bartered Bride in Paris, so the Czech public also began to take notice of Maurel. Šubert therefore came up with an offer for Maurel to introduce himself in the role of Kecal at the National Theatre in Prague. This required a complete French translation, but none was yet available. The two agreed that Maurel could also sing other roles from his repertoire in Prague, such as Iago, Don Giovanni, and Rigoletto. The autumn of 1897 was considered, but Maurel's guest appearance was constantly postponed for various reasons (including the cost), and ultimately it did not take place. See NA, AND collection, D 193-D 198 and D 232/76-81; also PNP LA, F. A. Šubert collection.

40) NM-MBS, Collection of Music-Related Documents, A 117-A 127.

41) Alfred Ernst (1860-1898) was a French music critic who translated Wagner's operas Die Meistersinger von Nürnberg and Götterdämmerung into French.

42) "Question importante: la traduction. Je ne pense pas qui il soit bon de s'adresser à Nuitter qui prendrait beaucoup de temps et ne ferait rien de bon, à preuve ses traductions de Wagner. Alfred Ernst, au contraire, a fait des traductions parfaites au double point de vue musical et litteraire et, si vous n'avez encore rien proposé à Nuitter, je crois qu'il vaudrait mieux attendre, dès que j’aurai votre réponse, je ferai suivant le cas, faire des demarches auprès de Alfred Ernst.” Maurel to Metternich, letter dated 7 March 1897, Monte Carlo. NM-MBS, Collection of Music-Related Documents, A 121.

43) Raoul Blondel (1864-1944) was a physician, composer, translator, and music critic, especially for the journals Le Monde Artiste, L'Écho de Paris, and L'Oeuvre; he used the pseudonym Raoul Brunel.

44) "[...] gestern eine Zusammenkunft mit Frau Maurel und dem Dr. Blondel gehabt in welcher mir die Übersetzung ins Französische vorgelesen und gesungen wurde. Diese ist ausgezeichnet und so typisch, so nahe am Texte also passend für die Musik daß ich nicht umhin konnte dem Dr. Blondel dazu zu beglückwünschen. Ich glaube beinahe daß seine Übersetzung dem böhmischen Original-Texte näher kommt als die deutsche!” Metternich to Šubert, letter dated 9 May 1897, Paris. PNP LA, F. A. Šubert collection. 
Champs-Élysées in the presence of 200-300 persons ${ }^{45}$ from the milieu of the aristocracy, politics, and the arts. ${ }^{46}$ The evening was divided into two parts. The first half consisted of musical and theatrical excerpts. At the opening, Laura de Houdiers danced a tarantella. There followed compositions by Charles M. Widor performed by C. Max and Countess Maupeou, a Russian song by Camille Erlanger sung by Victor Maurel, a duet from the opera Les voitures versées by François-Adrien Boieldieu sung by Jeanne Leclerc and Lucien Fugère, and a trio by Mozart performed jointly by L. Fugère Mrs. Lemaitre and Mrs. de Soria. The first part of the evening was concluded by actors from the Comédie-Française together with Anne Maurel in an excerpt from Molière's Tartuffe. ${ }^{47}$ Georges Vanor opened the second part of the evening devoted to The Bartered Bride, introducing the man Bedrrich Smetana and his music to the public, then the Skočná - Dance of the Comedians from Act III was heard. Next was the duet of Jeník and

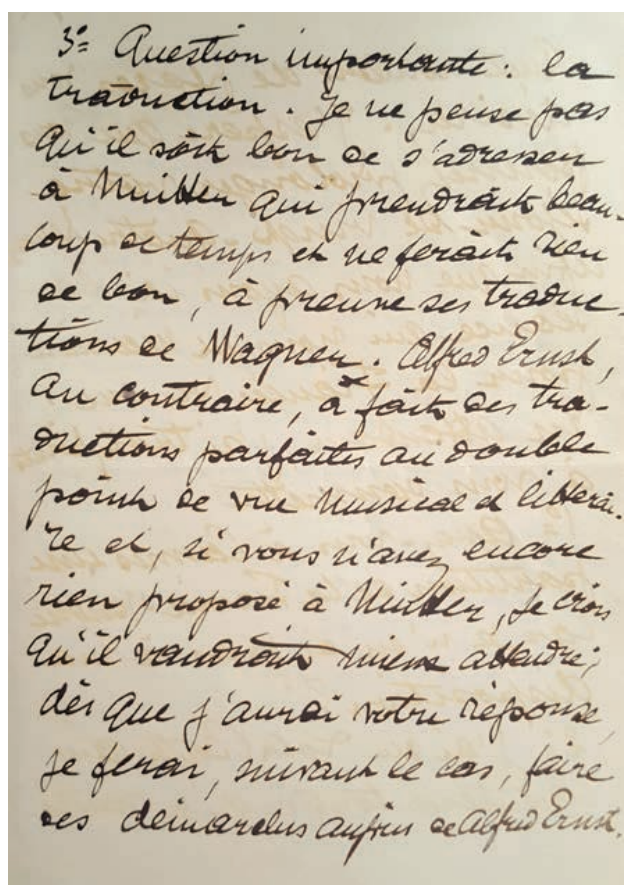

Victor Maurel: letter to Princess

Pauline von Metternich / Victor Maurel: dopis kněžně Paulině Metternichové

Autograph, Monte Carlo, 7 March 1897 /

Autograf, Monte Carlo, 7. 3. 1897

NM-MBS A 121 Mařenka "Jako matka požehnáním... Věrné milování", the terzetto with Kecal's refrain "Všecko je to hotovo", Mařenka's aria "Kdybych se co takového", the duet of Jeník and Mařenka "Tak tvrdošijná dívko jsi”, the terzetto of Jeník, Mařenka, and Kecal "Utiš se, dívko", then finally the duet of Jeník and Kecal "Znám jednu dívku". Originally the sextet "Rozmysli si, Mařenko" was also to have been heard, but unfortunately the singers did not have time to rehearse it. Apart from Countess Maupeou, the performers of the excerpts were ensemble members of the Opéra-Comique: Jeanne Leclerc, Jeanne Marié de l'Isle, Pierre Émile Engel, Ernest Carbonne, Herman Devriès,

45) The press reported there were 200 to 300 guests, but in her letter to Šubert dated 13 June 1897 from Paris, Anne Maurel said 400 guests were invited; see PNP LA, F. A. Šubert collection.

46) Among the guests were Prince Edmond de Polignac, Senator David Raynal, General Joseph Rébillot, the composers Jules Worms and C. M. Widor, the painters Giovanni Boldini, Jean Béraud, and Madeleine Lemairová, the sculptor Laurent Marqueste, the writers and brothers Alphonse and Ernest Daudet, the director of the "Comédie-Française" and novelist Jules Claretie, the director of the Opéra-Comique Léon Carvalho, the Milanese music publisher Edoardo Sonzogno, the former King of Annam living in Paris, the former ambassador in Vienna Albert Decrais, the financial baron Rodolphe Hottinguer, and Gustave Dreyfus. Le Figaro, vol. 43, 20 June 1897, no. 171, p. 2.

47) See Le Gaulois, vol. 31, 20 June 1897, no. 5705, p. 2; also Gil Blas, vol. 19, 19 June 1897, no. 6424, p. 2. 
and Victor Maurel. The very next day, Metternich sent Šubert a report about the evening's atmosphere. "It was wonderful, and Smetana enjoyed a triumph. The seven excerpts from 'The Bartered Bride' were applauded noisily. Mr. Georges Vanor was the master of ceremonies, in accordance with local custom, and he spoke briefly about Smetana's importance [...] Your beautiful bouquet was lying on the piano. It arrived in a fresh condition, and it looked impressive with the beautiful ribbons. Maurel surpassed himself and was showered with applause. Mr. Carbonne was superb, and the sparks flew in the duet between him and Miss Leclerc (both from the Opéra-Comique). That was the duet of Jenik and Mařenka from the last act. But nothing could beat the duet of Kecal and Jeník 'Ta má dukáty' from Act II, which served as the concluding fireworks." ${ }^{\text {" }}$ The Czech press confirmed what she said: "Smetana's music was found to be enchanting and entirely original, and everyone present expressed unanimously the wish that Smetana's work soon be performed in Paris. The Princess von Metternich-Sándor, representing the Czech National Theatre, gave a beautiful bouquet of orchids to Mrs. Maurel, who is owed the greatest thanks for the realisation of Princess von Metternich's idea; the flowers were sent by the management of the National Theatre in Prague [...]. A Czech text embroidered in gold on red and white ribbons read: 'Flowers and the arts bloom beneath the breath of spring and the enchanted hands of women. - The Czech National Theatre in Prague.' The ends of the ribbons were sewn into motifs of Czech folk embroidery with gold and garnets. Original folk costumes from Pilsen used for the opera were exhibited in the hall. The whole evening made an extraordinary and profound impression. There is hope that The Bartered Bride will be produced at the newly established 'Théatre lyrique' in Paris." ${ }^{39}$ Another Czech reporter lamented that the artists did not appear in the costumes that had been supplied. "It might have struck the French differently, but in my eyes it was truly strange to see Mařenka in a beautiful dress with a plunging neckline and with a big diamond star on her breast and Kecal and Jeník perfectly dressed in black tailcoats and white ties [...].50 The French translation was judged to be fluent but lacking in Czech character. "It is clearly a translation from German, a dilution of a dilution from which anything Czech has long since evaporated.51 The French press praised the artists' performances, and especially the duet sung by E. Engel and Countess Maupeou and the duet of Mr. Carbonne and Maurel, and it was hoped that the whole work would soon be heard in Paris. ${ }^{52}$ At the beginning of October,

48) 'Es war glänzend und Smetana hat weher Triumphe gefeiert. Die 7 Piècen aus der ,Prodana nevesta' sind acclamirt worden. Herr Georges Vanor - ein ,conférencier' wie sie hier zu Lande existieren, hat in kurzen Worten die Bedeutung Smetana's geschildert [...] Ihr schönes Bouquet lag auf dem Clavier. Es ist wunderbar frisch angelangt und nahm sich mit den prachtvollen Schleifen sehr gut aus. Maurel hat sich selbst übertroffen und wurde mit Beifall überschüttet. Vortrefflich war Herr Carbonne und das Duo zwischen ihm und Frl. Leclerc (beide von der Komischen Oper) zündete. Es ist das Duo zwischen Hanns und Marie im letzten Akt. Doch nichts konnte das Duo Kecal's und Hanns übertreffen: Sie hat Dukaten aus dem 2ten Akt welches als SchlußFeuerwerk." Metternich to Šubert, letter dated 20 June 1897, Paris. PNP LA, F. A. Šubert collection.

49) Národní listy, vol. 37, 21 June 1897, no. 170, p. 3.

50) XYZ [?]: Smetanův večírek u pana Maurela (A Smetana Soiree at the Home of Mr. Maurel), Národní listy, vol. 37, 25 June 1897, no. 174, p. 1 (hereinafter XYZ).

51) Ibid.

52) Le Figaro, vol. 43, 20 June 1897, no. 171, p. 2. 
a second performance of a fragmentary form of The Bartered Bride was again to take place in the Maurel's salon. "Everyone in Paris is now in a craze over Smetana, and the Maurels were asked to hold a Smetana soirée again in the autumn. ${ }^{.54}$ Metternich then asked Blondel for a complete translation of the opera, but that did not lead to the taking of this practical step towards a complete performance of Smetana's opera on one of Paris's stages. According to the journalists, this was to be expected - although the Smetana evening "was a wonderful success in every respect, [...] it involved only one part of that elegant Parisian salon milieu, while the actual musical and theatrical circles were not affected by this, and the general public knew nothing at all about it. Further attempts will be necessary, or energetic efforts that will see through a production of Smetana's opera on a public stage defiantly in spite of everything."55 Once again, getting The Bartered Bride produced in Paris had to wait.

\section{From correspondence between the translator Raoul Blondel and Pauline von Metternich}

Metternich's further tireless efforts are documented by her correspondence with Raoul Blondel. "Last year I saw Mr. Albert Carré, ${ }^{56}$ and I spoke with him about The Bartered Bride. As I expected, he was very reserved, and it seemed to me that he regards Smetana as 'worthless.' [...] I shall ask W... [Weinberger] about his terms. He is the most peculiar publisher I have ever encountered. He prevents the works he represents from being performed! [...] Of course Maurel would be a wonderful choice for the role of Kecal; but because Mr. Carré does not want Smetana and Maurel is engaged at the Opéra-Comique, we unfortunately have to accept that we will not be seeing him play that beautiful role in the coming years. I have the idea that The Bartered Bride could be performed once or twice by the Société des Grandes Auditions Musicales, and I have spoken with Countess Greffulhe about it. Might you have a word about it with Mr. Lamoureux, ${ }^{57}$ just in passing? It seems to me that this enterprising musician is the only one who might be able to realise this undertaking. ${ }^{58}$ Blondel's response brought a further revelation.

53) Gil Blas, vol. 19, 23 June 1897, no. 6428, p. [2].

54) "In Paris schwärmt nun alles für Smetana und sind Maurel's gebeten worden im Herbste noch eine Smetana Soirée zu veranstalten!” Metternich to Šubert, letter dated 28 June 1897, Mattstall. PNP LA, F. A. Šubert collection.

55) XYZ, op. cit. in footnote no. 50.

56) Albert Carré (1852-1938) was a French actor, dramatist, librettist, and stage director. From 1898 to 1913 and from 1918 to 1925 he was the executive director of Paris's Opéra-Comique. Before that he was the executive director of the Théâtre du Vaudeville.

57) Charles Lamoureux (1834-1899) was a French conductor and violinist. In 1881 he established the important Orchestre Lamoureux, which was affiliated with the Théâtre des Champs-Élysées. The orchestra was founded as the Société des Nouveaux-Concerts for the purpose of promoting contemporary music and the works of Richard Wagner in particular. Under Lamoureaux's leadership, for example, Tristan und Isolde was given its Paris premiere (Nouveau Théâtre, 1899). Later, the orchestra specialised in French music, giving the premieres of works by Maurice Ravel, Gabriel Fauré, and Claude Debussy.

58) 'J'ai vu M. Albert Carré l’année dernière pour lui parler de la Fiancée vendue. Comme je m'y attendais, il s'est montré d'une réserve extrême et m'a paru traiter Smetana comme une ,non-valeur'. [...] je vais faire demander à W... ses conditions. C'est l'éditeur le plus curieux qu'il m'ait été donné de rencontrer dans toute mon existence. Il empêche que les ouvrages qu’il a acquis soient représentés! [...] Évidemment Maurel serait 
"Yesterday I finally saw the director Mr. Carré at the Opéra-Comique, and he passed on to me the information from your letters. He was very kind, as was Mr. Messager, ${ }^{59}$ the music director, who was also present. But they both told me that the budget at the Opera-Comique does not permit the performing of more than one foreign work per year. This year it is the opera Hänsel und Gretel, and next year it will be Pagliacci. He also spoke with me about the subject of The Bartered Bride, which seems too local to him to catch on for their audience. He has objections to the stuttering character [Vašek], which seems impossible to him, and according to him, the role of Kecal is hard to comprehend in France. He agrees that the music is enchanting, and that is why he went to hear the work twice in Vienna. But according to him, today the public is much more discriminating than before with respect to librettos. ${ }^{100}$ Because the character of Smetana's comic opera ruled out producing it at the Opéra Garnier, there was no choice but to find a different opera stage. The newly established Théâtre Lyrique de la Renaissance came increasingly under consideration. In December 1899 Blondel informed Metternich that the Théâtre Lyrique and its music director Danbé ${ }^{61}$ were seriously considering a production of The Bartered Bride. ${ }^{2}$ Metternich reassured Šubert: "I am not giving up about a performance in Paris, and I am trying to win over Lamoureux for it. [...] Dr. Blondel, an avid proponent of Smetana's music, has again written to me to say that with regard to enabling a performance of 'The Bartered Bride, he has spoken with the management of the new opera theatre. The gentlemen do not seem to be unwilling, but now it again depends upon Mr. Weinberger because the young company does not possess great financial resources, so the publisher should not make exaggerated demands!"63

merveilleux dans le rôle de Keçal; mais puisque M. Carré ne veut pas de Smetana et que Maurel est engagé l’Opéra-Comique, il faut bien renoncer à lui voir créer ce beau rôle d’ici à quelques années. J’ai idée que la Fiancée vendue pourrait être représentée une fois ou l'autre par la Société des Grandes Auditions Musicales et j'en ai dit un mot à Madame la comtesse Greffulhe. Ne pourriez-vous pas, une fois en passant, en parler à M. Lamoureux? Il me semble que ce musicien entreprenant serait le seul qui pourrait mener à bonne fin l'enfreprise en question." Metternich to Blondel, letter date 3 Nov. 1899, Vienna. In: BRUNEL, Raoul [BLONDEL]: Souvenirs à propos de "la Fiancée vendue”, Le Ménestrel, vol. 90, 26. 10. 1926, no. 43, p. 443.

59) André Messager (1853-1929) was a French composer, conductor, and first conductor at the Opéra-Comique.

60) "J’ai enfin vu hier M. Carré à l’opera Comique, et je lui ai dit tout ce que me disaient vos lettres. Il a été très aimable ainsi que $M$. Messager, le chef de la musique, qui était présent. Mais tous deux m'ont dit que le cahier des charges de l'opéra Comique ne permettaient pas de monter plus d'une pièce étrangère nouvelle par an. Cette année, c'est Hansel et Grötel. L’an prochain, c'est i Pagliacci. Il m’a également parlé du sujet de la Fiancée vendue, qu'il trouve de caractère trop local pour intéreser son public. Le rôle du bègue lui parait impossible et celui de Kezal difficile à comprendre en France. Il convient que la musique est charmante, car il a entendu la pièce deux fois à Vienne. Mais il dit qu'aujourdhui le public est devenu beaucoup plus exigeant qu'autrefois pour le livret.” Blondel to Metternich, letter dated 20 Nov. 1899, [Paris]. NM-MBS, Collection of Music-Related Documents, A 129.

61) Jules Danbé (1840-1905) was a French violinist, composer, opera conductor, and the first conductor at the Théâtre lyrique de la Renaissance.

62) Blondel to Metternich, letter dated 24 Dec. 1899, Paris. NM-MBS, Collection of Music-Related Documents, A 130 .

63) "ich wegen einer Aufführung in Paris nicht nachlasse und Lamoureux dafür zu interessieren trachte. [...] Dr. Blondel der eifrige Förderer der Musik Smetana's hat mir wieder geschrieben um mir zu sagen daß er mit dem Direktorium des neuen lyrischen Theaters Rücksprache getroffen habe wegen der Ermöglichung einer 
In January 1900, it seemed that the management of the Théâtre Lyrique de la Renaissance had made a definitive decision, but the theatre was denied the subsidy for which it had applied. Danbé informed Blondel of their new terms: if the theatre secures 20 performances of the work, the theatre shall to the contrary be guaranteed a revenue of 3,500 francs for each performance by the depositing of 10,000 francs to a bank account to cover the theatre's possible expenses. If the necessary revenue were to be achieved during the production, the entire deposited amount would be refunded, and if not, the bank would make payment to the theatre from the deposit. The theatre believed that its terms were justified because the usual revenue for one evening was 4,000 francs on average (sometimes up to 9,000). It was asserted that there was actually no risk and that the guarantee was demanded only to show the government that things could not be done without subsidies. ${ }^{64}$ And so it was that in Prague Subert and the National Theatre Association, ${ }^{65}$ the general manager of the National Theatre Josef Herold, the president of the Czech Academy Josef Hlávka, Prince Lobkowicz, and František L. Rieger signed an appeal in the press "For Smetana's 'Bartered Bride" for public fundraising intended to facilitate the performing of the opera in Paris during the World Exhibition. The appeal, which was signed by individuals and institutions, elicited mixed feelings among the public. While some were willing to make donations for the cause, to others it seemed beneath the dignity of Smetana's work. The journal Dalibor, which printed the appeal, published a sharp reaction: "the works of Bedrich Smetana do not need [...] favouritism and begging. Is Smetana's standing beneath that of Gounod, Verdi, Wagner, and other composers from around the world? [...] It is our belief that a perfect success can be achieved if the French will produce 'The Bartered Bride' because it is the work of an ingenious composer, but not because Czechs paid for it. [...] we can easily just wait until our French friends learn enough geography to know that Prague is not located somewhere in Hungary and realise that we are, while a small nation, still highly culturally advanced and among the first in the arts and especially in music."66 This opposition was intensified by the false report that The Bartered Bride was supposed to be performed at the Théâtre Lyrique in the Rue Vivienne, a little, out-of-the-way theatre that was "more of a concert salon than a theatre, with about 150 seats, without room for an orchestra, which would not fit there unless it were to be squeezed into the space occupied by a grand piano. [...] It would be a blasphemy, an irony even to think of giving a presentation there of the most glorious flowering of Czech music, the lovely daughter of the muse of poor Smetana! They would be spending our money to desecrate 'The Bartered Bride' there. [...] we condemn the performance of 'The Bartered Bride' for 10,000 francs of our money

Aufführung der ,Verkauften Braut’. Die Herren scheinen nicht abgeneigt zu sein es hängt aber jetzt wieder sich von Herrn Weinberger ab da das junge Unternehmen nicht über große Fonds verfügt und daher der Verleger keine übertriebenen Ansprüche fallen sollte!” Metternich to Šubert, letter dated 9 Nov 1899, Dresden. PNP LA, F. A. Šubert collection.

64) Blondel to Metternich, letter dated 20 March 1900, [Paris]. NM-MBS, Collection of Music-Related Documents, A 131.

65) The committee of the National Theatre Association undertook to contribute 2,000 crowns.

66) Dalibor, vol. 22, 14 April 1900, nos. 17-18, p. 141. 
in an undignified atmosphere!!'67 There was also a lack of trust in the Paris production, which would supposedly spend Czech money to turn "Vašek into a stupid cretin" and the scene with the comedians into "a crudely stupid circus act". by, among other things, a statement from the new director of the National Theatre Gustav Schmoranz, ${ }^{69}$ who set things right by pointing out that two theatres had been confused, and that the theatre in question was actually the Théâtre Lyrique de la Renaissance, which is one of Paris's most elegant theatres and has a capacity of ca. 1,000 seats. ${ }^{70}$

Blondel explained the complicated situation surrounding Paris's theatres to Metternich. "I would never allow The Bartered Bride to be performed in a hall with 190 seats and 12 musicians. [...] at a little theatre in the Rue Vivienne, old comic operas are played that most Parisians do not even know. In fact, the théâtre lyrique was based in the della Renaissance theatre hall until last March. It was too small there, although there are 800 to 900 seats. The director made a very good business deal when he rented his hall very expensively to an operetta ensemble during the World Exhibition, and when he moved his theatre company to the theatre Château-d'Eau, where there are 1,800 seats. The Bartered Bride should be played there. At the moment when it was announced that the theatre would shut down and would not reopen until September, all of the artists had already been chosen. There is no need to be too sorry about that: at this hall, which is too remote [from the city centre], sales would have been minimal. It would have seemed too far away to people. Anyway, it is already beginning to be apparent that the theatres are mistaken when they expect a high level of sales this summer. The public, after all, is giving preference to the exhibition [World Exhibition], which is held during the day and has plenty of attractions. Mr Milliaud ${ }^{1}$ has promised me that he will present The Bartered Bride at the beginning of the season in the original hall, to which he is returning beginning in September. ${ }^{12}$ However, the Théâtre lyrique de la Renaissance found itself in

67) "Prodaná nevěsta" do Pařižze ("The Bartered Bride" to Paris), Dalibor, vol. 22, 21 April 1900, no. 19, pp. 145-146.

68) Ibid.

69) Gustav Schmoranz took over the management of Prague's National Theatre in 1900.

70) G. S. [SCHMORANZ, Gustav]: Kvypraveni "Prodané nevěsty" do Paříže (On Sending "The Bartered Bride" to Paris), Národní listy, vol. 40, 1 May 1900, no. 119, p. 2 [4].

71) The Milliaud brothers were the directors of the Théâtre lyrique de la Renaissance from March 1899 until March 1900.

72) "Jamais je n’aurais peu penser à faire exécuter la fiancée vendue dans une salle de 190 places avec 12 musiciens: petit thèâtre de la rue Vivienne où l’on joue de vieux opéras comiques et que la plupart des Parisiens ne connaissent même pas. Le thèâtre lyrique véritable était installé dans la salle du thèâtre dela Renaissance jusqu'au mais dernier. Il s'y est trouvé trop à l'étroit bien qu'il y eut 800 à 900 places. Le directeur a cru faire une belle affaire en louant sa salle très cher à une troupe d'opèrette pendant l'Exposition et en transportant son thèâtre dans la salle du Chateau d'Eau, qui renferme 1800 places. C'est là qu'on devait joue la Fiancée Vendue. Les artistes étaient déjà choisis, quand on vient d'annoncer que le thèâtre fermait ses portes pour ne rouvrir qu'en septembre. Il ne faut pas trop le déplorer: dans cette salle trop lointaine les recettes étaient nulles: les gens chic trouvaient cela trop loin. D’ailleurs on commence à comprendre que les thèâtres ont eu tort de compter sur de grosses recettes pendant cet été. Le public préfére aller à l’Exposition, qui est avant le soir et où il y a une foule d'attractions. M. Milliaud n'a promis qu'il monterait la Fiancée dès la réouverture, dans son ancienne salle, dont il reprendra possession en septembre." Blondel to Metternich, letter dated 26 April 1900, Paris. NM-MBS, Collection of Music-Related Documents, A 133. 
serious financial difficulties, and in the end it went bankrupt. Fortunately, this happened in time for the generous donors from Prague, who therefore did not lose money by investing in the company. The negotiations were also interrupted because of a change of management at the National Theatre. "I am not losing hope. I will wait patiently for the new stage that will one day agree to a performance of The Bartered Bride. [...] Unfortunately our director Mr. Šubert has been replaced by a 'Young Czech', but who is not worth much."

In connection with the publication of Ritter's book in French about Bedřich Smetana, ${ }^{74}$ speculation again began to appear in the press that The Bartered Bride might soon appear on the stage of the Opéra Comique, but Ritter was very doubtful about the realistic possibilities for The Bartered Bride to appear on a Paris stage at the time. According to him, Paris was a city that "believes itself to be at the forefront of everything and cannot stand the thought that it should admire a work that the rest of Europe has been applauding for 40 years without Paris having given its permission. We respectfully ask our readers to forgive us this pessimism. Smetana's music is some of the most beautiful, most noble, most purely simple, and most dignified. [...] But I truly tremble at the thought that Paris in its self-sufficiency might unjustly view Smetana's music as having nothing to offer the French musicians and public."75 A new stimulus for the promotion of The Bartered Bride on Parisian stages was its performance in Brussels at the Théâtre Royal de la Monnaie on 23 February 1907 in a translation by Raoul Blondel. Blondel told Metternich that the director Carré should also attend the Brussels premiere, having told him he was very interested in the work. Blondel gave him a printed copy of his French translation that had just been published in Leipzig. He expressed the hope that the success of The Bartered Bride in Brussels might convince Carré to produce it at the Opéra-Comique. ${ }^{76}$ Unfortunately, the edition of Blondel's translation was marred by inappropriate alterations and by misprints. Blondel was convinced that the opera could have been more successful if it had been performed with greater care and enthusiasm. Instead of two sets, only one was used - a very plain village green with a fountain at the centre and flowing water that was extremely distracting. The theatre replaced the recitatives with spoken texts, and that was a fatal error according to Blondel. The prose that was used underscored the division of the opera into individual numbers, making it give the impression of being half a century older. ${ }^{77}$

73) "Je ne perds pas courage. J’attendrai patiemment qu'une nouvelle scène accepte un jour la Fiancée vendue. [...] Hélas! notre directeur, M. Subert, est remplacé par un, Jeune Tchèque' qui ne le vaut ni de près ni de loin.” Metternich to Blondel, letter dated 9 May 1900, Vienna. In: BRUNEL, Raoul [BLONDEL]: Souvenirs à propos de "la Fiancée vendue", Le Ménestrel, vol. 90, 2. 11. 1926, no. 44, p. 454 (hereinafter BRUNEL).

74) RITTER 1907, op. cit. in footnote no. 3.

75) RITTER 1909, op. cit. in footnote no. 2, p. 286.

76) Blondel to Metternich, letter dated 18 Feb. 1907, Paris. NM-MBS, Collection of Music-Related Documents, A 134.

77) BRUNEL, op. cit. in footnote no. 73, p. 455. 


\section{The journey to the premiere at the Opéra-Comique in 1928}

Another opportunity to promote Smetana's opera in Paris came just before the war in 1913 when the violinist Jan Kubelík came to Paris to give several concerts. The first of them took place at the Théâtre des ChampsElysées, the construction of which had just been completed; in 1913 its director Gabriel Astruc $^{78}$ was planning to present an Italian opera with Emmy Destinn and a Russian ballet. ${ }^{79}$ Kubelík proposed the performing of Smetana's opera to Astruc, who promised to support the idea if Kubelík would play some Czech compositions between acts. According to Victor Darras, ${ }^{80}$ Astruc was negotiating with the National Theatre by telegram. The director was demanding a guarantee of 20,000 francs for the evening. Astruc, to the contrary, was expecting a deficit of 50,000 for a cycle of Smetana operas (The Bartered Bride, Dalibor, Hubička - The Kiss, and Dvě vdovy - The Two Widows). In order to make

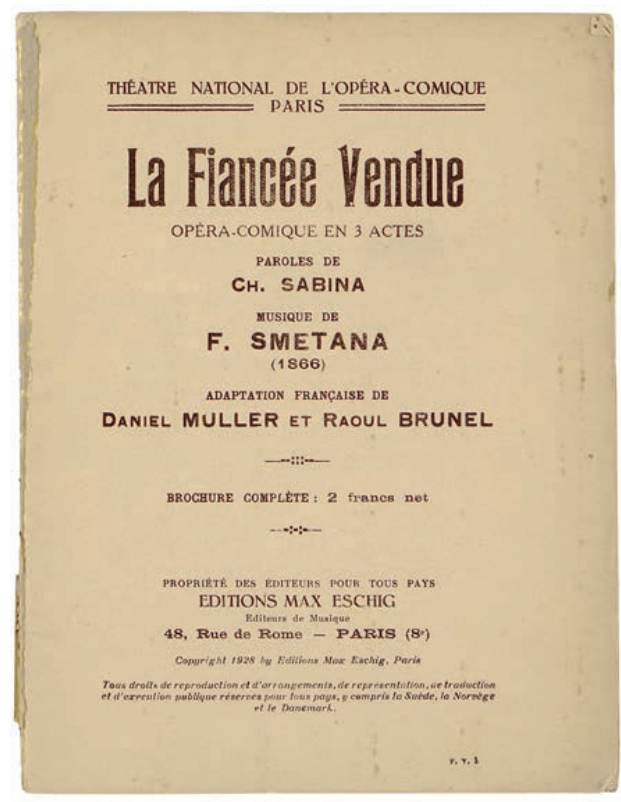

French translation of the libretto by D. Muller and R. Brunel / Francouzský preklad libreta od D. Mullera a R. Brunela

Print, Editions Max Eschig, Paris, 1928 /

Tisk, Editions Max Eschig, Paříž, 1928

NM-MBS L 119/a the tour possible for the National Theatre, Kubelík was prepared not only to appear, but also to cover half of the deficit, if any. Astruc and Schmoranz finally reached an agreement. Karel Kovařovic was to have conducted the orchestra with the Czech soloists Destinn, Mařák, Burian, Ludikar et al. The Bartered Bride was to have been played first by Czech and then by French artists with the collaboration of the aforementioned Czech singers who knew French. Although the tour, which had been planned for 19 - 24 June 1913, was sponsored by the bank Bohemia, because of financial problems it was postponed at the last moment until the autumn of 1914. But then war broke out. ${ }^{81}$

The founding of the Czechoslovak state in 1918 again brought the question of a production of Smetana's opera in Paris to the forefront. In 1925 the director Jaroslav Kvapil involved himself in the matter, turning over to the Ministry of Foreign Affairs a very detailed proposal

78) Gabriel Astruc (1864-1938) was a French journalist, dramatist, impresario, and the founder and director of the Théâtre des Champs-Élysées.

79) It was at the Théâtre des Champs-Elysées that the Ballets Russes gave the premiere of Igor Stravinsky’s Rite of Spring on 29 May 1913.

80) The real name of the politician and journalist Viluš Crkal (1884-1946) was Vilém Antonín Hypolit; after his marriage he used the name Victor Darras.

81) DARRAS, V.: Česká hudba ve Francii před válkou: $K$ premiére Prodané nevěsty (Czech Music in France before the War: On the Premiere of The Bartered Bride), Národní listy, vol. 68, 27 Oct. 1928, no. 298, p. 1. 
for theatrical realisation, including a technical scenario for a French production, and he took part in the first negotiations with the management of the Opéra-Comique. The former opera singer and wife of the Czechoslovak ambassador in Paris Pavla Osuská (née Vachková) became the new major proponent of The Bartered Bride.

The Bartered Bride did not have as much difficulty making its way to any other city in the world as to Paris. In 1928, Paris became the last major European city where Smetana's opera was premiered. A long sixty years had passed between the first attempts to have it performed there and the first full production, and with the contributions of so many people who tried everything possible to breach the dam blocking access to Paris, those years brought many hopes followed by many disappointments. This winding road did not finally reach its destination until 26 October 1928, when for the $10^{\text {th }}$ anniversary of the founding of Czechoslovakia at the Opéra-Comique in Paris in the presence of French president Gaston Doumergue and important cultural figures, critics, and artists, The Bartered Bride was finally first performed in a translation by Daniel Muller and Raoul Brunel. The stage design for the production was by Josef Wenig, the stage director was Georges Ricou, and the conductor was Louis Masson. There were 15 more performances, and the production remained in the repertory until 1932. However, not even this premiere brought Smetana's opera a more permanent life in Paris.

Address: Kateřina Viktorová, Muzeum Bedřicha Smetany, Novotného lávka 1, 11000 Praha 1, Czech Republic

E-mail: katerina.viktorova@nm.cz 


\section{Prosazování Smetanovy Prodané nevěsty v Pařžži}

\section{Katerina Viktorová}

„Smetana bohužel nemá [...] zevnějšich kvalit lesku, elegance, řekněme onoho ,clinquant, jež sluši Pařiži. O něho se zajímati budou a to jako o phenomène zemépisný mnohem později v cyklech historických koncertů. [...] A i opery, počaté dle námětů, jež si Pařiž neodepře nazvati vieux jeu, a dle librett, jež až na jedno jsou známé nedostatečnosti!! Dodejme, že toto výjimečné libretto Prodané nevěsty spočivá, ač utěšeně, na námětu tak prostičkém, že by se statečni snobové, již tvoři vètšinu ctitelü Monny Vanny, Pelléasa, Arianny et Barbe Bleu, ${ }^{1}$ pokládali za ponížené, kdyby se mèli o ni zajímati. Dnešního dne sotva které divadlo projeví snahu vypraviti kus podobný, ač neni-li k tomu takřka donuceno hnutím veřejného minění. [...] Prodaná nevěsta byla by mèla ve Francii pronikavý úspěch před třiceti lety; dnes, mám strach, aby za zmènèných pomèrů nebylo již k tomu príliš pozdè!"²

Tato slova napsal v roce 1909 hudební kritik a autor první francouzské knihy o Smetanovi a jeho díle William Ritter, který stavěl Smetanu mezi Berlioze a Wagnera. ${ }^{3}$ Už z citovaných řádků lze vytušit, jak těžce se Smetanova Prodaná nevěsta na paříżská jeviště prosazovala. Díky předehře, která se hrávala na koncertech, úplně neznámá francouzskému publiku nebyla. První pokusy prosadit operu v Paříži, která byla považována za hlavní město opery, učinil koncem šedesátých let 19. století sám Smetana. Na doporučení Františka Lad. Riegera, který se v šedesátých letech snažil v Paříži připravit půdu pro uvedení některých oper českých skladatelů, a Raffaela Vitaliho ${ }^{4}$ Smetana napsal pařížskému divadelnímu agentovi Adolphu Giacomellimu ${ }^{5}$ a svou operu mu spolu

Předložená práce vznikla za finanční podpory Ministerstva kultury v rámci institucionálního financování dlouhodobého koncepčního rozvoje výzkumné organizace Národní muzeum (DKRVO 2019-2023/22.III.b, 00023272).

Autorka děkuje všem, kdo jí při práci pomohli: Magdalena Pechlátová s autorkou významně spolupracovala na překladech úryvků z dopisů a dobového tisku z francouzštiny; Petra Kulovaná prepsala z kurentu ukázky z německých dopisů Pauliny Metternichové. Překlady všech cizojazyčných citací jsou dílem autorky studie, pokud není uvedeno jinak.

1) Monna Vanna, opera Henryho Févriera z roku 1909; Pelléas a Mélisanda, opera Clauda Debussyho z roku 1902; Ariana a Modrovous, opera Paula Dukase z roku 1907.

2) RITTER, William: Frncouzi [!] a Smetana, Hudební revue, roč. 2, 1909, č. 5, s. 285-286 (dále RITTER 1909).

3) RITTER, William: Smetana, Editions Alcan, collection Les Maitres de la Musique, Paris 1907 (dále RITTER 1907).

4) Raffaele Vitali (1815-1896), dirigent v Théâtre Italien v Pařízii.

5) Adolphe Giacomelli (1825-1893), vydavatel hudebních a divadelních časopisů, pařǐžský divadelní agent. 
se zasláním jejího provozovacího materiálu představil. " „Melodie by mohly mít pro Pařiz kouzlo novinky a vzbudit větši zájem než obvykle, protože vycházeji z nevyčerpatelné pokladnice ve svètè ještè málo známého charakteru českého národa, které jdou v rytmice a melodice svou vlastní cestou. [...] Se kterým pařižským divadlem má být tato česká nevěsta zasnoubena podle francouzského vytřibeného vkusu zůstává na vašem rozhodnutí." Když sešlo z francouzského překladu, ${ }^{8}$ Smetana dal na své náklady opsat partituru a klavírní výtah Prodané nevěsty a libreto přeložit do němčiny Emanuelu Züngelovi. ${ }^{9}$ Zaslané materiály se ale v Pař́ži ztratily. ${ }^{10}$

\section{Velká propagátorka Smetanovy hudby}

Věc na dlouhou dobu téměř usnula, dokud se jí naplno a systematicky nechopila velká propagátorka Smetanovy hudby kněžna Paulina Metternichová. ${ }^{11}$ Zbožňovala hudbu obecně, a když si některého skladatele „adoptovala“, vytrvale ho podporovala. Její nadšení pro Smetanovu operu a usilovnou snahu uvést ji v Pařiži zaznamenal František Adolf Šubert ve své vzpomínkové knize. „Jsou sice již dnes i mimo Čechy tisícové ctitelů velikého mistra,

6) Viz zápis ze 14. 8., in Diářové zápisky Bedřicha Smetany 1869: „Opera ,Prodanou nevěsta' zasláná do Pařiše." Autograf, in: Kalendář Koruny české na obyčejný rok 1869, Ed. Grégr, Praha [1868] (Národní muzeum - České muzeum hudby - Muzeum Bedřicha Smetany, dále jen NM-MBS, S 217/1109; v odkazech dále Diářové zápisky Bedricha Smetany 1869).

7) „Les mélodies pourrient avoir pour Paris les charme de la nouveauté et inspirer un plus grand intérets qu’autrefois, parcequ'elles sont pleinment puisées de la source impuisible - encore peu connue - de la maniére du peuple tchèque, - qui vont dans la Rythmique et melodique leur propre chemin du sentiment. [...] À quel théatre de Paris cette fiancée tchèque doit être mariée au gout français purifié - cela reste naturellement votre resolution." Smetana Giacomellimu, koncept dopisu ze 14. 8. 1869, [Praha]. Čistopis dopisu, psaný zřejmě ve francouzštině, je dnes nezvěstný. Jeho francouzský koncept (vznikl překladem Smetanova německého konceptu) se dochoval v opise Zdeňka Nejedlého s poznámkou, že originál psaný cizí rukou se nalézá ve vlastnictví Zdenky Heyduškové (MÚA AV ČR, fond Z. Nejedlý, kart. 19, XIV/4). In: MOJŽÍŠOVÁ, Olga - POSPÍŠIL, Milan - VOJTĚŠKOVÁ, Jana - KROUPA, Jiří K.: Bedřich Smetana. Korespondence II (1863-1874), Národní muzeum a Nadace pro dějiny kultury ve střední Evropě ve spolupráci s KLP - Koniasch Latin Press s.r.o., Praha 2020, s. 262-263 (dále MOJŽÍŠOVÁ - POSPÍŠIL - VOJTĚŠKOVÁ - KROUPA). Giacomelliho odpověd' na Smetanův dopis není známa.

8) O probíhajícím překladu do francouzštiny Smetana informoval Isaaca Philipa Valentina v dopise již 13. 2. 1868. Proč nebyl překlad nakonec realizován, není známo. Viz MOJŽÍŠOVÁ - POSPÍŠIL - VOJTĚŠKOVÁ KROUPA, op. cit. v pozn. 7, s. 193-195.

9) Viz Diárové zápisky Bedřicha Smetany 1869, op. cit. v pozn. 6.

10) $O$ osudu zásilky provozovacích materiálů k Prodané nevěstě viz Terezie Bubeníčková Smetanovi, dopis z 8. 6. 1870. Viz MOJŽÍŠOVÁ - POSPÍŠIL - VOJTĚŠKOVÁ - KROUPA, op. cit. v pozn. 7, s. 284-285. Zásilka bohužel nebyla frankovaná a divadelní agentury neplatily poštovné za balíky. Partitura zůstala deponovaná v Pařiži na ministerstvu vnitra, kde bylo třeba zaplatit 50-60 franků. Bubeníčková požádala svého př́tele Louise Légera, aby se o zásilku postaral, a poslala mu poukázku na 60 frankủ k jejímu vyplacení. Další osudy materiálu nejsou známy a dnes je nezvěstný.

11) Paulina Metternichová-Sándorová (1836-1921), manželka rakouského velvyslance v Paříži pocházející z uherské hraběcí rodiny Sándorů ze Slavnice. V jejich vyslaneckém paláci se v šedesátých letech 19. století scházel výkvět tehdejšího francouzského uměleckého světa. V prosazování svých cílů se mohla opírat o své kontakty na dvoře císaře Napoleona III. a v diplomatických i šlechtických kruzích. Po smrti manžela, knížete Richarda Metternicha v roce 1895, přijala ke knížecímu jménu také své dívčí jméno uherského rodu. Zasloužila se mj. o první uvedení Wagnerova Tannhäusera v roce 1861 v Opéra Le Peletier. 
neznám však nikoho, kdo by pro jeho genia a jeho ,Prodanou'tak byl roznícen a o šírení jeho slávy tak vytrvale se zasazoval, jako kněžna Metternichová. To souvisí s temperamentem kněžny, s nevysychatelnou svěžestí její energie a s bezpř́kladnou houževnatostí, s jakou kráčí za cílem, pro který jeji mysl a jeji duch kdy zahořely." Poprvé viděla Prodanou nevěstu jako čestná předsedkyně výstavního výboru v roce 1892 na Mezinárodní hudební a divadelní výstavě ve Vídni v podání souboru pražského Národního divadla. Právě vídeňský úspěch přinesl opeře mezinárodní uznání a otevřel jí cestu na evropská a posléze i světová jeviště. ${ }^{13}$ Už o necelý rok později, 2. dubna 1893, nastudovalo operu v německém překladu Maxe Kalbecka Divadlo na Vídeňce ${ }^{14}$ a brzy následovala další. O tomto představení referoval francouzský deník s doporučením, že by opera měla být uvedena brzy také v Paříži. „Skutečnou politickou událostí posledních čtrnácti dnu - kdo by to byl kdy řekl? - jest predstavení české opery v Divadle na Videňce. [...] Je to neuvěritelné! Prodaná nevěsta skladatele Smetany, o kterou jde, je komickou operou v každém ohledu roztomilou. Libreto nestojí za moc, ale je tu hezká role pro basso buffo, křupanského dohazovače na vesnických svatbách. [...] Zápletka je poněkud dètinská. Oživena je ale rozkošnou hudbou, o nižz lze řict, jako by se čerstvě vylíhla z Mozarta a zároveň oplývá slovanskými melodiemi zvláštního pưvabu. Mimo to jsou tu velmi pěkné tance a české národni kroje lahodi oku. Všimnète si, pane Carvalho!n Zdá se mi, že Prodaná nevěsta šikovně upravená, by se Pařižanưm velice líbila, zejména vezmou-li se v úvahu politické sympatie. V každém př́padè je to malé mistrovské dílo, ačkoliv svètu trvalo skoro tricet let, než si ho všimlo. ${ }^{" 6}$

12) ŠUBERT, František Adolf: Kněžna Pavlína z Metternich-Sándorů a Bedřich Smetana, in: Moje vzpomínky I. Z uplynulých dob, tiskem a nákladem České grafické společnosti „Unie“, Praha 1902, s. 55 (dále ŠUBERT).

13) Uvádění Prodané nevěsty ve světě zmapovala výstava Nevěsta prodaná do ciziny v NM-MBS (autorka Kateřina Viktorová, 6. 3. 2019 - 4. 10. 2021).

14) Více REITTEREROVÁ, Vlasta - REITTERER, Hubert: Vier Dutzend rothe Strümpfe... Zur Rezeptionsgeschichte der „Verkauften Braut" von Bedřich Smetana in Wien am Ende des 19. Jahrhunderts, Verlag der Österreichischen Akademie der Wissenschaften, Wien 2004; REITTEREROVÁ, Vlasta: Dvě první vídeňské Prodané nevěsty a jejich představitelé (Theater an der Wien 1893, Hofoper 1896) / The First Two Viennese Productions of Prodaná nevěsta and Their Performers (Theater an der Wien 1893, Hofoper 1896), Musicalia, roč. 8, 2016, č. 1-2, s. 22-36 (česká verze), s. 37-58 (anglická verze).

15) Léon Carvalho (1825-1897), francouzský impresário a režisér, v letech 1876-1887 a 1891-1897 ředitel pařižské Komické opery (Opéra-Comique).

16) „Le véritable événement politique de la quinzaine - qui l'eût jamais cru? - c'est la représentation d’un opéra tchèque au Théâtre an der Wien. [...] C'est à ne pas y croire! La Fiancée vendue, du compositeur Smetana, dont il s'agit, est un opéra-comique en tous points charmant. Le livret ne vaut pas grand'chose. Mais il y a un joli rôle pour une basse bouffe, celui d'un paysan entremetteur de mariages champêtres. [...] L'intrique, on le voit, est tant soit peu enfantine. Mais tout cela est animé par une musique bien délicieuse, comme qui dirait du Mozart fraîchement éclos et noyé dans des mélodies slaves d'une saveur particulière. Avec cela, il y a des ballets très jolis, et les costumes nationaux de la Bohême réjouissent l'oeil. Avis à M. Carvalho. Il me semble que la Fiancée vendue, habilement adaptée, devrait plaire beaucoup aux Parisiens, étant données au surplus les sympathies politiques. Dans tous les cas, c'est un petit chef-d'oeuvre en son genre, bien que le monde ait mis trente ans à s'en apercevoir." VOGT, Walter: Courrier de Vienne, Le Figaro, roč. 39, 12. 4. 1893, č. 102, s. 4. 
Metternichová byla rozhodnuta zasadit se veškerým svým politickým i společenským vlivem o uvedení Prodané nevěsty v Komické opeře. ${ }^{17}$ Jednat začala i s ředitelem Národního divadla Františkem A. Šubertem, který sám v této věci činil mnohé kroky. Jeho pracovní korespondence obsahuje dopisy s mnohými osobnostmi, které se o seznámení pařížské veřejnosti s Prodanou nevěstou zasadili. ${ }^{18}$ Paulina Metternichová navštívila 3. listopadu 1893 představení Prodané nevěsty v Národním divadle. ${ }^{19}$ „Vyprávěla jsem p. Carvalhovi tolik krásného a dobrého o pražském prèstavení, že pokud nás nevyslyší, nerozumí svým zájmům. Pokud bude jeho odpověd' odmitavá, obrátím se jinam, konkrétnè na hraběnku Greffulheovou, ${ }^{20}$ která je prezidentkou, grandes auditions musicales' a každý rok uvádí s predními umělci operu, která neni pařižskému publiku dosud známá. ${ }^{(11}$

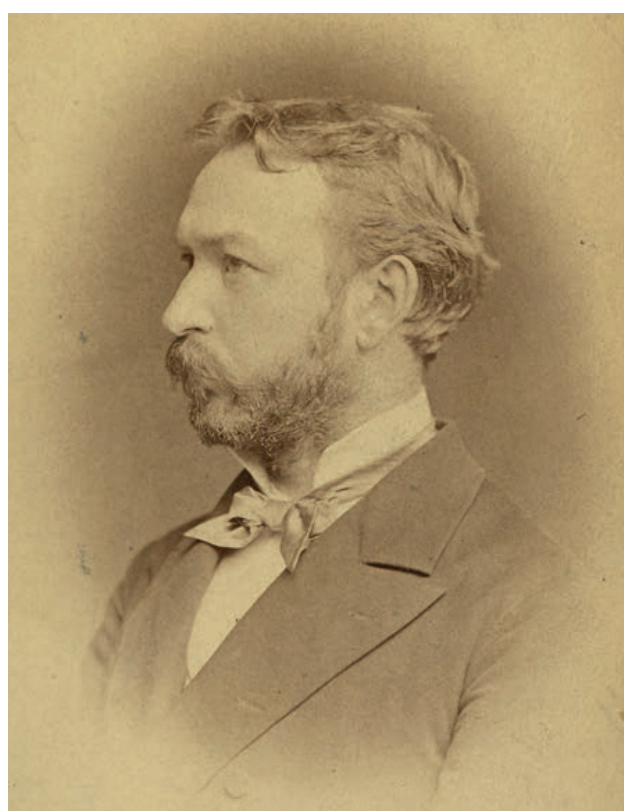

František Adolf Šubert (1849-1915)

Photograph, Jan Mulač, Prague, 1892 / Fotografie, Jan Mulač, Praha, 1892

NM-MBS inv. no. / inv. č. 3437

17) Komická opera (Théâtre de l’Opéra-Comique) vznikla v roce 1801 sloučením dvou nejvýznamnějších pařižských komických divadel Théâtre Feydeau a Salle Favart. Provozovala komický opernížánr, který bylv Paříži velmi populární již od 18. století. Její dnešní budova byla otevřena v roce 1898 na náměstí pojmenovaném po skladateli F. A. Boieldieuovi. V druhé polovině 19. století byla Opéra-Comique velkým konkurentem Opéra Garnier a řada premiér tehdejších populárních skladatelů se konala právě v ní. V původní budově, která vyhořela, byla uvedena roku 1875 poprvé Bizetova Carmen a kolem roku 1900 a v letech pozdějších byly v premiéře uvedeny např. opery Charpentierova Luisa, Debussyho Pelléas a Mélisanda či Dukasova Ariana a Modrovous.

18) Např. s tehdejším ředitelem pařižského Théâtre du Vaudeville Albertem Carré, ředitelem pařížské OpéraComique Léonem Carvalhem, ředitelem vlámského divadla $v$ Anvers Edwardem Keurvelsem, pořadateli Světové výstavy v Paříži, redaktorem časopisu Journal musical Baudouinem la Londre, redaktorem deníku Gil Blas Albertem de Lapeyrousem, redaktorem týdeníku Le Ménestrel Oscarem Berggruenem, či s nakladatelstvím Choudens, které vydávalo francouzské opery 19. století a kterému Šubert doporučoval, aby na tyto opery získalo publikační a provozovací právo pro Francii a Belgii. Viz Národní archiv, fond Archiv Národního divadla (dále NA, fond AND), D 183-D 201 a D 232/78-81; a Literární archiv Památníku národního písemnictví (dále PNP LA), fond F. A. Šubert (nezpracovaný).

19) ŠUBERT, op. cit. v pozn. 12, s. 56.

20) Élisabeth Greffulheová (1860-1952), patronka vědy a umění. V roce 1890 založila společnost Société des grandes musicales. Organizovala koncerty komorní hudby i divadelní představení. V roce 1890 uvedla např. Berliozovu operu Béatrice a Bénédict v Théâtre de l’Odéon a zasloužila se o první pařížské uvedení Tristana a Isoldy Richarda Wagnera v říjnu 1899. Byla známou královnou salonů pařížského Faubourg Saint-Germain. Inspirovala mnoho umělců - stala se předobrazem postavy vévodkyně z Guermantes v Hledáníztraceného času Marcela Prousta a skladba Pavane, op. 50 Gabriela Faurého je hraběnčiným hudebním portrétem.

21) „Ich habe Herrn Carvalho so viel Schönes und Gutes über die Vorstellung in Prag erzählt daß wenn er uns kein Gehör schenkt er seine Interessen nicht versteht. In dem Falle einer ablehnenden Antwort werde ich mich anderswo hinwenden und das nämlich an die Gräfin Greffulhe welche Präsidentin der ,grandes auditions 


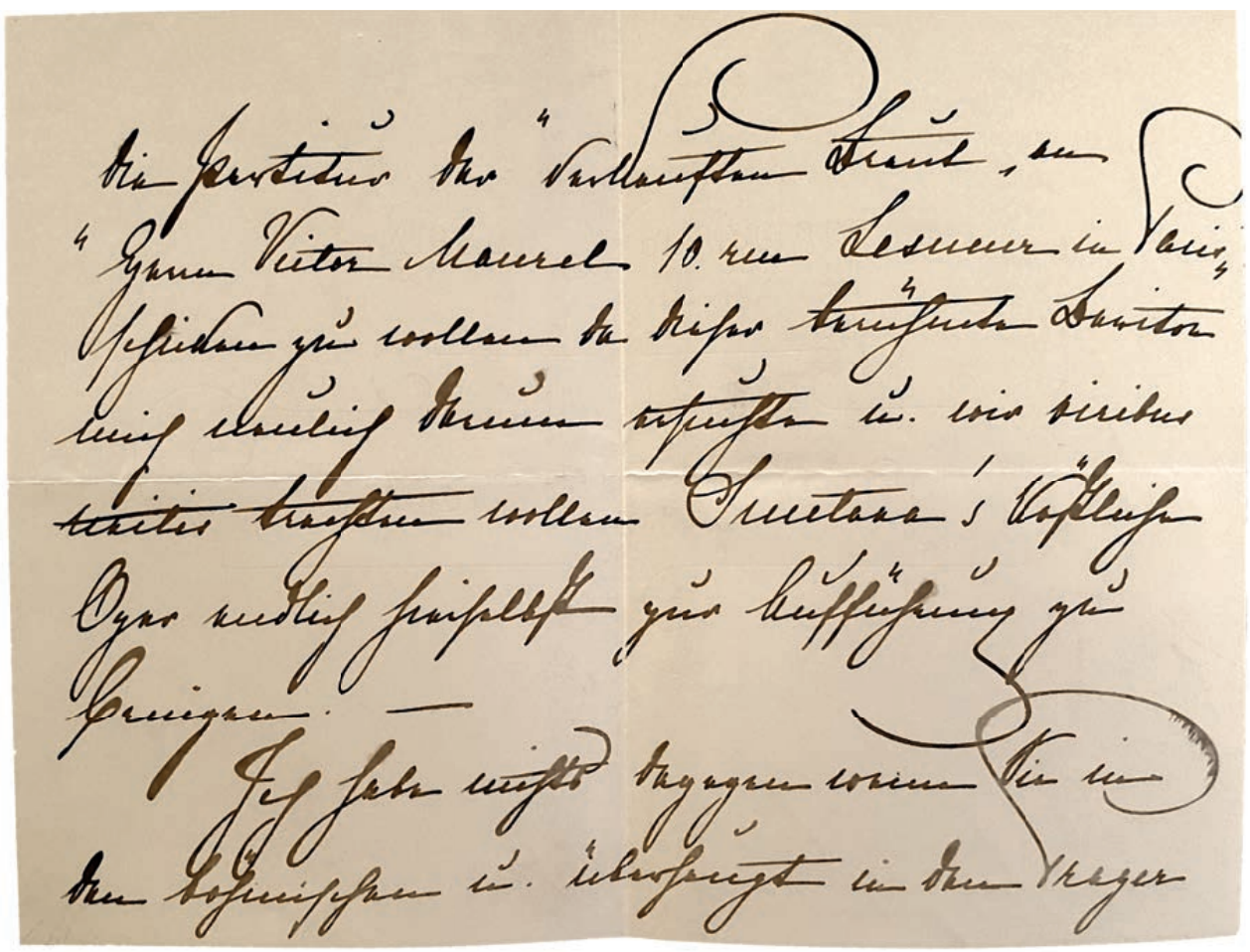

Pauline von Metternich: letter to František A. Šubert / Paulina Metternichová: dopis Františku A. Šubertovi Autograph, Paris, 10 June 1896 / Autograf, Pařiž, 10. 6. 1896

PNP LA, collection / fond F. A. Šubert

Věc se však nedařila tak, jak Metternichová předpokládala. Pro svou myšlenku nadchla významného francouzského barytonistu Victora Maurela, ${ }^{22}$ který se chtěl sám ujmout role Kecala. „Na Smetanu nezapomínám a chci Vás požádat, abyste obratem zaslal partituru ,Prodané nevěsty' panu Victoru Maurelovi na 10 rue Lesueur v Pařiži, protože mne tento slavný barytonista nedávno žádal a my viribus unitis se o to zasadit chceme, aby se zde skvostná Smetanova opera konečnè dočkala provozování. Nemám nic proti tomu, když prostřednictvím českých a pražských novin oznámite, že se vážně zasazujeme, aby se představení uskutečnilo. Nebot' takto se dostane věc do francouzských časopisů, a jakmile pro sebe ziskáme tisk, vyhráli jsme a Smetana triumfuje v Pařiži stejně jako všude jinde! [...] P. S. Victor Maurel je nyní a právem považován za prvního barytonistu Francie. ${ }^{23}$

musicales' ist und alljährlich eine dem Pariser Publikum unbekannte Oper durch Künstler allerersten Ranges aufführen läßt." Metternichová Šubertovi, dopis z 10. 11. 1893, Plasy. PNP LA, fond F. A. Šubert.

22) Victor Maurel (1848-1923), ve světové premiére představitel Verdiho Jaga v Otellovi (1887) a Falstaffa (1893). K jeho výrazným rolím patřil Hamlet, Don Giovanni, Rigoletto nebo Faust. Již v roce 1869 byl angažován do milánské La Scaly, v londýnské Covent Garden se představil ve Wagnerově Lohengrinu, Tannhäuserovi i Bludném Holand'anovi. Vystupoval v Metropolitní opeře v New Yorku, v pařížské Opeře i v Komické opeře.

23) „Ich vergesse nicht Smetana und komme Sie zu bitten umgehends die Partitur der ,Verkauften Braut an Herrn Victor Maurel 10. Rue Lesueur in Paris schicken zu wollen da dieser berühmte Bariton mich neulich darum aufsuchte und wir viribus unitis trachten wollen Smetana's köstliche Oper endlich hierselbst zur 
Francouzský týdeník uveřejnil rozsáhlý článek o Smetanovi, v němž referent konstatoval, že nejen po celém Německu „všichni kritici se o něj zajímají, organizuji se mimořádná představení jeho dèl; obchodníci s hudbou prodávají jeho portrét [...]. Jediná Francie se prozatím obejde bez Smetany. Domnívám se ale, že je to jen otázka měsícư. ${ }^{24}$ Jednu chvíli to už vypadalo, že se k uvedení Prodané nevěsty opravdu schyluje. Napovídaly tomu zprávy jak v českém, tak ve francouzském tisku. Například o tom, že opera bude provedena v Pařiži i v Miláně a při té př́ležitosti vydá Josef Weinberger ${ }^{25}$ partituru opery ve francouzském a italském překladu. ${ }^{26}$ Pařížský deník se zase dožadoval, aby Prodaná nevěsta byla v příští sezóně provedena v Komické opeře. „Doslýcháme se, že se vážně uvažuje o uvedení Prodané nevěsty příští zimu v Komické opeře. Ta, která byla u nás kdysi ochranitelkou Tannhäusera [Metternichová], [...] z toho bude mit radost. [...] Upř́mnè si prejeme, aby Pařiž, [...] bývalé hlavní mèsto umèni toužicí po znovuziskání svého významu, nečekala déle než na príští sezónu, aby uvedla Prodanou nevěstu. Bude to nejkrásnějši ze všech večerů - krásný a dojemný ve všech ohledech." ${ }^{27}$ Uvedení opery potvrzovaly i další deníky, které Prodanou nevěstu jmenovaly spolu s Massenetovou Popelkou, Mozartovým Donem Giovannim, Wagnerovým Bludným Holand'anem a operami Pêcheurs de Saint-Jean Charlese M. Widora, Kermaria Camilla Erlangera a Dalila nebo Vanina od Émila Paladilha jako nové premiéry nadcházející sezóny Komické opery. ${ }^{28} \mathrm{Z}$ těchto informací patrně vycházel i český tisk, který rovněž ohlašoval, že „Prodaná nevěsta byla definitivně prijata ku provozování v Komické opeře a to v období právě počínajicím. ${ }^{29}$ Někteří o tom však pochybovali: „Oproti tvrzenim mnohých listů musime konstatovati s živým politováním, že provedení Smetanovy,Prodané nevěsty v Pařiži stalo se velice pochybným. Vzdor všelikému horlivému úsili kněžny Pavliny Metternichovy, kteráž pro ukrácení dlouhé své chvíle zavedla jediný sport sympatický, sport blahodějnosti. Jaké jsou překážky? Správa Velké Opery

Aufführung zu bringen. Ich habe nichts dagegen wenn Sie in den böhmischen und überhaupt in den Prager Zeitungen bekannt geben lassen daß wir uns hier ernstlich einsetzen um eine solche Aufführung zu ermöglichen denn dadurch kommt die Geschichte in die französischen Journale und wenn wir uns einmal die Presse für uns haben dann haben wir gewonnenes Spiel und Smetana triumphiert in Paris so wie überall! [...] Victor Maurel gilt jetzt, und mit Recht als der erste Bariton Frankreichs." Metternichová Šubertovi, dopis z 10. 6. 1896, Pařiž. Originál je uložen v PNP LA, fond F. A. Šubert.

24) „tous les critiques s'occupent de lui, on organise des exécutions spéciales de ses oeuvres; les marchands de musique vendent son portrait; [...] La France seule, pour le moment, se passe de Smetana. Mais j'imagine que ce n'est plus qu’une affaire de mois;" Un nouveau génie musical. Frédéric Smetana, Revue Bleue, la revue politique et littéraire, roč. $24,14.4$. 1894, č. 15, s. 469.

25) Josef Weinberger (1855-1928), vídeňský hudební nakladatel, který byl dědici pověřen zastupováním Smetanových děl.

26) Národní listy, roč. 35, 9. 5. 1895, č. 127, s. 3.

27) „Il nous revient qu'il est grandement question de donner, l'hiver prochain, la Fiancée vendue à l'Opéra-Comique. Celle qui fut chez nous, autrefois, la protectrice de Tannhoeuser, [...] qu'elle n'en ait la joie. [...] Nous faisons des voeux sincères pour que Paris, $[. .$.$] ancienne capitale de l'art soucieuse de reconquérir son rang,$ n'attende pas au delà de la saison prochaine qu'on fasse paraitre à ses yeux la Fiancée vendue. Ce sera une soirée belle entre toutes - belle et touchante à tous égards." UN MUSICIEN: Un chef d'oeuvre bohémien à Paris, Le Gaulois, roč. 30, 29. 7. 1896, č. 5376, s. 1.

28) La Liberté, roč. 31, 29. 8. 1896, č. 11604, s. 4. Stejnou zprávu uveřejnil i deník Le Matin, roč. 13, 28. 8. 1896, č. 4565, s. 3.

29) Dalibor, roč. 18, 3. 10. 1896, č. 40, s. 318. 
,divadla lyrického, ${ }^{30}$ odvolává prý se na to, že nelze na její jevišti vưbec ze zásady (!) dávati dilo hudební, zasahujicí v obor opery komické, ano prý až do operettního oboru - i odkazuje ,Prodanou nevěstu' na pařižskou operu komickou. Ale opera komická zase odvolává se na to, že ,Prodanou nevěstu' nemůže prý provésti, poněvadž nemá - balletu. Jest to pravda či záminka?’s1

\section{Francouzský tisk o Prodané nevěstě v reakci na její premiéru ve vídeňské Dvorní opeře}

Zvýšený zájem francouzského tisku o Prodanou nevěstu vyvolala její premiéra ve vídeňské Dvorní opeře 4. října $1896 .^{32}$ Kromě hodnocení vídeňské premiéry články vyjadřovaly také přání, že, když už operu uvádějí téměř všechna německá divadla, ${ }^{33}$ je načase, aby se jí ujalo také některé z divadel pařížských. „Ve výtečném provedení orchestru proudí život, který v našich dvou pařižských opernich divadlech [Opéra Garnier a Komická opera] zcela chybí. Ti videňští roštáci jsou ztělesněním hudby! [...] byla to pro mne nemalá satisfakce, když jsem vidèl něco jiného, než jen to přešlapováni na mistě, na které si naše Opera udělala monopol. Doufám, že brzy bude Prodaná nevěsta uvedena také v Pařiži. "34 Tento článek vznikl i pod dojmem pražské návštěvy představení Prodané nevěsty téhož referenta. „Pan Salvayre byl predstavením v Praze (představeními) [navštívil celkem 3 různé opery] potěšen a v dopise mně zaslaném zdioraznil velký rozdíl, který panuje mezi názory ve vídeňské Dvorní opeře a v českém Národním divadle. Zůstává mi rozum stát nad tím, proč se režisér ve Vidni nesnažil co možná nejvice přibližit pojetí pražského divadla a výpravu nepojal typičtěji, národněji! [...] Podle Salvayra by prý Carvalho provedl, Prodanou nevěstu'špatně, protože by mu v mnoha ohledech chybèly síly. Na Kecala by mèl jen Fugèra ... Sbor je u nèj bídný a balet je pod neustálou kritikou! Chtějí nyní založit, theatre universel' a kapitál už prý maji pohromadè - účastníci mi prislíbili, že nejprve provedou,Prodanou nevěstu? Až do roku 1900 [rok konání Světové

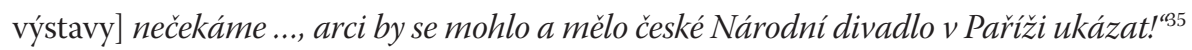

30) Opéra Garnier (také Palais Garnier).

31) Listy z Prahy, Plzeňský Obzor. SvobodomysIný list pro Plzeň a západní Čechy, roč. 5, 18. 11. 1896, č. 93, s. 1.

32) Dvorní opera (Hofoper) s uvedením Prodané nevěsty trochu otálela, dokonce ještě před ní stihla uvést Smetanovu Hubičku (27. 2. 1894) i Tajemství (27. 3. 1895). Teprve tři roky po úspěšném provedení v Divadle na Vídeňce se uskutečnila premiéra Prodané nevěsty ve Dvorní opeře.

33) Během devadesátých let 19. století byla Prodaná nevěsta uvedena v mnoha evropských městech, zejména v německy mluvícím prostoru: Berlín, Frankfurt nad Mohanem, Drážd'any, Cáchy, Lipsko, Kolín nad Rýnem, Brémy, Mnichov, Hamburk.

34) „Dans la belle exécution de l’orchestre circule la vie qui manque absolument, je le maintiens, dans nos deux théâtres lyriques parisiens. Ah! ces coquins de Viennois sont la musique même! [...] ce n'a pas été, pour moi, une mince satisfaction de voir autre chose que les piétinements sur place dont notre Opéra semble avoir accaparé le monopole. A bientôt, j'espère la Fiancée vendue à Paris." SALVAYRE, G. B.: À l'Opéra Imperial de Vienne. La Fiancée vendue, Gil Blas, roč. 18, 10. 11. 1896, č. 6203, s. [3].

35) „Herr Salvayre war über die Aufführung in Prag (die Aufführungen) sehr entzückt und hat den gewaltigen Unterschied welcher zwischen der Auffassung in der Wiener Hofoper und im böhmischen Nationaltheater ganz besonders in seinem Briefe an mich hervorgehoben. Mir bleibt es unerklärlich daß der Régisseur in Wien nicht getrachtet hat der Auffassung im Prager Theater möglichst nahe zu kommen und die Mise en scène typischer, nationaler zu gestalten! [...] Carvalho würde nach Salvayre's Ansicht die ,Verkaufte Braut' schlecht aufführen indem ihm die Kräfte in vielfacher Beziehung fehlen. Er hätte nur Fugère für die Rolle des Kecal... 
O tom, jak na francouzskou kritiku Smetanova opera zapůsobila, se dozvídáme z další reakce na premiéru ve vídeňské Dvorní opeře. „Vyšel jsem z opery [...], okouzlen, potěšen, plný láskyplného obdivu k českému géniu, jedním slovem přesvědčený smetanovec. [...] Smetanovi př́znivci - a je jich plno nejen v Čechách a Rakousku - se ho neboji prirovnávat k Mozartovi. Možná je to príliš [...] tato malá česká vesničanka [Prodaná nevěsta] propaguje Smetanovo jméno po celé Evropě. [...] pan Carvalho, který má velkorysé srdce, by ji neměl odmitnout pohostinnost. [...] V žánru a tradici komické opery si nedokážu představit lepši operu, než je Nevěsta. [...] Role koktavého Vaška je dokonalá; scéna, kdy je vzteklý a rozzlobený Kecal pronásledován posměšky sboru, připominá, aniž by byla horší, kousky z Lazebníka sevillského. Scéna komediantů, výstup principála, svedení hlupáka Esmeraldou, mají zaručený efekt. Slavnostni sbor venkovanů, predehra, pijáci, taneční hudba, která uzavírá prvni dèjství a zahajuje druhé; tento tanec je sám o sobè tak originální, s tleskáním a velmi výraznou mimikou, bude mit jistě velký úspěch. [...] Pokud jde o, citovou'část, pařižské publikum, které vždy mělo rádo melodie, jich tam najde spoustu a znamenitých. Dokonce i wagneriáni, pokud budou chtit, tam najdou leitmotiv: jedná se o velice jemnou frázi, která se představí v predehře, objevuje se v prvním dějství, v duetu milencư a prochází celým dílem [...]. Kéž má pan Carvalho tu odvahu zabalit si kufr a při první př́ležitosti, pokud takještě neučinil, běžet do Vidně nebo do Prahy; toho výletu nebude litovat. ${ }^{\text {‘6 }}$ Metternichová i Šubert byli přesvědčeni, že tento pozitivní ohlas v tisku jejich věc výrazně posune kupředu a pomůže ředitele Carvalha přesvědčit, aby Prodané nevěstě dveře Komické opery konečně otevřel. Kněžna začala také jednat se Smetanovými dědici o zhotovení překladu opery do francouzštiny.

\section{První fragmentární uvedení Prodané nevěsty v Paříži roku 1897}

Metternichová se s Maurelem rozhodli představit Paříži Prodanou nevěstu prostřednictvím vybraných úryvků. „Zamýšlime nyní, aby v květnu nebo červnu zazněly některé části z opery

Der Chor ist bei ihm miserabel und das Ballet-corps unter h.der Kritik! Man will jetzt ein ,theatre universel' gründen und sollen die Kapitalien schon da sein - die Theilnehmer haben mir die Zusage gemacht im allererster Reihe die ,Prodaná nevesta' aufgeführen! Bis zum Jahre 1900 warten wir nicht ... jedenfalls könnte und sollte darin das böhmische Nationaltheater in Paris sich zeigen!" Metternichová Šubertovi, dopis z 6. 12. 1896, Schoppenwihr. PNP LA, fond F. A. Šubert. Národní divadlo nebylo do Paříže na Světovou výstavu v roce 1900 nakonec pozváno.

36) „Je suis sorti de l’Opéra, [...] charmé, ravi, plein d’un sorte d’affectueuse admiration pour le doux génie du maître tchèque, en un mot smetanien convaincu. [...] Les partisans de Smetana, - ils sont légion en Bohême et en Autriche, - ne craignent pas de le comparer à Mozart. C'est peut-être beaucoup [...] la petite paysanne [Fiancée vendue] tchèque est en train de promener par toute l'Europe le nom de Smetana [...] M. Carvalho, qui a le cœur généreux, ne saurait lui refuser l'hospitalité. Je ne puis concevoir de pièce qui soit, nieux que la Fiancée, dans le genre et la tradition de l’opéra-comique. [...] Le rôle du bègue Wenzel est parfait; la scène où Kezal, berné, furieux, est poursuivi par les railleries du chœur, rappelle, sans trace d'infériorité, tel ou tel morceau du Barbier de Séville. La scène des saltimbanques, l'annonce du bateleur, chef de la troupe, la présentation des artistes, la séduction du crétin par Esmeralda, sont d'un effet sûr. Le choeur des paysans en fête, à l'ouverture; celui des buveurs, l'air de danse qui termine le premier acte et qui commence le second; cette danse, elle-même, d'un caractère si original, avec des battements de mains et une mimique si expressive, auront un vif succès, cela est certain. [...] Quant à la partie, sentimentale' le public parisien, qui a toujours eu une vieille tendresse pour les mélodies, y en trouvera à foison, et d’exquises. Les wagnériens même, s'ils le 
a za tímto účelem uspořádat velké soirée u Maurelů. [...] přeposílám Vám současnè dopis pana Nuittera, ${ }^{37}$ který, jak se zdá, je překlad [Prodané nevěsty] v próze!?"38 Ohledně uvedení fragmentů Prodané nevěsty i podmínek následného Maurelova event. hostování v Praze s barytonistou i jeho manželkou Annou mezi lety 1896 a 1898 intenzivně korespondoval Šubert. ${ }^{39}$ Bližší vhled do př́íprav salonního představení nám dokládá také Maurelova korespondence Paulině Metternichové. ${ }^{40}$ Jejím hlavním tématem bylo obsazení jednotlivých rolí a francouzský překlad libreta. Ten totiž nebyl vídeňským zástupcem Smetanových oper Weinbergerem Nuitterovi svěřen. „Důležitá otázka: překlad. Nemyslím, že by bylo dobré obrátit se na Nuittera, kterému to bude trvat dlouho a nevytvoři nic dobrého, dokladem jsou jeho preklady Wagnera. Naopak Alfred Ernst by vyhotovil výborné překlady ze dvou hledisek, jak z hudebního, tak z literárního. Pokud jste ještě Nuitterovi nic nenabidla, bylo by lepší počkat, jakmile budu mít Vaši odpověd, zařílim se podle toho a eventuálně se obrátím na Alfreda Ernsta ${ }^{41}{ }^{442}$ Metternichová nakonec oslovila Raoula Blondela. ${ }^{43}$ Blondel neuměl česky, a tak nevycházel ze Sabinova textu, ale z německého překladu Maxe Kalbecka. „[...] včera jsem měla schioku s paní Maurelovou a dr. Blondelem, při niž mi byl predčitán a zpíván překlad do francouzštiny. Je vynikajicí a tak typický, tak blizký textu [původnímu] a hodící se k hudbě,

veulent, y pourront découvrir un leitmotiv: c'est une phrase délicieuse, qui, préparée dans l’ouverture, apparaît au premier acte, dans le duo des amoureux, et se maintient à travers la pièce [...]. Que M. Carvalho, en conclusion, ait le courage de préparer sa valise, et, au premier moment, s'il ne l'a déjà fait, qu'il coure à Vienne ou à Prague; l'excursion ne lui laissera aucun regret." BOUSQUET, Henri: La „Fiancée vendue" de Smetana a l'Opéra Royal de Vienne, Journal des débats politiques et littéraires, roč. 108, 15. 10. 1896, č. 288, s. 3.

37) Charles Nuitter (1828-1899), francouzský dramatik, libretista a prekladatel. Do francouzštiny přeložil např. Weberova Oberona, Verdiho Macbetha a Aidu i Wagnerovy opery Bludný Holand'an, Tannhäuser, Lohengrin. 38) „Wir gedenken nun im Mai oder Juni in Paris einige Sachen aus der Oper zu Gehör bringen zu lassen und zwar soll zu diesem Zwecke eine große Soirée bei Maurel's stattfinden. [...] übersende Ihnen gleichzeitig einen Brief Herrn Nuitter's welcher, wie es scheint, eine Übersetzung in Prosa!?" Metternichová Šubertovi, dopis z 26. 3. 1897, Paříz. PNP LA, fond F. A. Šubert.

39) O úspěchu salonního představení Prodané nevěsty v Pařiži totiž referoval i český tisk, a tak Maurela začalo registrovat i české publikum. Proto přišel Šubert s nabídkou, aby se Maurel v roli Kecala představil v Národním divadle $v$ Praze. K tomu byl nutný kompletní francouzský překlad, který ovšem tehdy ještě nebyl $\mathrm{k}$ dispozici. Oba se shodli, že by Maurel mohl v Praze zazpívat i další role ze svého repertoáru jako Jaga, Dona Giovanniho a Rigoletta. Uvažovalo se o podzimu roku 1897. Maurelovo hostování se však stále oddalovalo a z různých (i finančních) důvodů k němu nakonec nedošlo. Viz NA, fond AND, D 193-D 198 a D 232/76-81; také PNP LA, fond F. A. Šubert.

40) NM-MBS, fond Nenotové rukopisy a tisky, A 117-A 127.

41) Alfred Ernst (1860-1898), francouzský hudební kritik, do francouzštiny přeložil Wagnerovy opery Mistři pěvci norimberští a Soumrak bohủ.

42) „Question importante: la traduction. Je ne pense pas qui il soit bon de s'adresser à Nuitter qui prendrait beaucoup de temps et ne ferait rien de bon, à preuve ses traductions de Wagner. Alfred Ernst, au contraire, a fait des traductions parfaites au double point de vue musical et litteraire et, si vous n'avez encore rien proposé à Nuitter, je crois qu'il vaudrait mieux attendre, dès que j'aurai votre réponse, je ferai suivant le cas, faire des demarches auprès de Alfred Ernst." Maurel Metternichové, dopis ze 7. 3. 1897, Monte Carlo. NM-MBS, fond Nenotové rukopisy a tisky, A 121.

43) Raoul Blondel (1864-1944), lékař, skladatel, překladatel a hudební kritik zejména v Le Monde Artiste, L'Écho de Paris a L’Oeuvre, používal pseudonym Raoul Brunel. 
že jsem nemohla jinak, než dr. Blondelovi gratulovat. Dokonce si myslim, že jeho překlad se bliži českému originálu více než německý!'44

Fragmentární uvedení Prodané nevěsty se uskutečnilo 19. června 1897 v salonu palácového domu manželů Maurelových v ulici Logelbach ve čtvrti nedaleko parku Monceau a ulice Champs-Élysées za přítomnosti dvou set až tří set osobnostít ${ }^{45} \mathrm{z}$ řad aristokracie, politiky i umění. ${ }^{46}$ Večer byl rozdělen do dvou částí. První polovinu vyplnily hudební a činoherní ukázky. Na úvod zatančila Laura de Houdiersová tarantelu. Následovaly skladby Charlese M. Widora přednesené Ch. Maxovou a hraběnkou Maupeouovou, ruská píseň z pera Camilla Erlangera v podání Victora Maurela, Jeanne Leclercová a Lucien Fugère zazpívali duet z opery Les voitures versées od Françoise Adriena Boieldieua, Mozartovo trio přednesly spolu s L. Fugèrem dámy Lemaitre a de Soria. První část večera zakončili herci z Comédie-Française spolu s Anne Maurelovou ukázkou Molièrova Tartuffa. ${ }^{47}$ Druhou polovinu večera věnovanou Prodané nevěstě uvedl Georges Vanor, který publiku představil osobnost a hudbu Bedřicha Smetany, a zazněla Skočná - Tanec komediantů ze třetího jednání. Dále následoval duet Jeníka a Mařenky „Jako matka požehnáním... Věrné milování, tercet s Kecalovým refrénem „Všecko je to hotovo“, árie Mařenky „Kdybych se co takového“, duet Jeníka a Mařenky „Tak tvrdošíjná dívko jsi“, tercet Jeníka, Mařenky a Kecala: „Utiš se, dívko“ a konečně duet Jeníka a Kecala „Znám jednu dívku“. Původně měl zaznít také sextet „Rozmysli si, Mařenko“, ale bohužel jej zpěváci nestihli nastudovat. Úryvky přednesli, až na hraběnku Maupeouovou, členové Komické opery - Jeanne Leclercová, Jeanne Marié de l'Isle, Pierre Émile Engel, Ernest Carbonne, Herman Devriès a Victor Maurel. Hned následující den Metternichová o atmosféře večera referovala Šubertovi. „Byl skvělý a Smetana slavil triumf. Sedm ukázek z,Prodané nevěsty bylo hlasitě vyvoláváno. Pan Georges Vanor - konferenciér, jak je zde zvykem, stručně vyličil Smetanưv význam [...] Vaše krásná kytice ležela na klavíru. Došla svěži a s nádhernými stuhami vypadala impozantnè. Maurel překonal sám sebe a byl zasypán potleskem. Výtečný byl pan Carbonne a v duetu mezi ním a sl. Leclercovou (oba z Komické opery) to jiskrillo. Je to duet Jeníka a Mařenky z posledního jednání. Ale nic nemohlo překonat duet Kecala a Jeníka ,Ta má dukáty‘z 2. jednání, který pusobil jako závěrečný

44) „,...] gestern eine Zusammenkunft mit Frau Maurel und dem Dr. Blondel gehabt in welcher mir die Übersetzung ins Französische vorgelesen und gesungen wurde. Diese ist ausgezeichnet und so typisch, so nahe am Texte also passend für die Musik daß ich nicht umhin konnte dem Dr. Blondel dazu zu beglückwünschen. Ich glaube beinahe daß seine Übersetzung dem böhmischen Original-Texte näher kommt als die deutsche!" Metternichová Šubertovi, dopis z 9. 5. 1897, Paříž. PNP LA, fond F. A. Šubert.

45) Tisk uváděl 200 až 300 hostů, Anne Maurelová ve svém dopise Šubertovi z 13. 6. 1897 z Paříže zmínila pozvání 400 hostů, viz PNP LA, fond F. A. Šubert.

46) Mezi hosty se objevili např́klad kniže Edmond Polignac, senátor David Raynal, generál Joseph Rébillot, skladatelé Jules Worms a Ch. M. Widor, malíri Giovanni Boldini a Jean Béraud, maliřka Madeleine Lemairová, sochař Laurent Marqueste, spisovatelé bratři Alphonse a Ernest Daudetové, ředitel „Comédie-Française" romanopisec Jules Claretie, reditel Komické opery Léon Carvalho, milánský hudební nakladatel Edoardo Sonzogno, bývalý král Annamský žijící v Paříži, bývalý velvyslanec ve Vídni Albert Decrais, finančníci baron Rodolphe Hottinguer a Gustave Dreyfus ad. Le Figaro, roč. 43, 20. 6. 1897, č. 171, s. 2.

47) Viz Le Gaulois, roč. 31, 20. 6. 1897, č. 5705, s. 2; také Gil Blas, roč. 19, 19. 6. 1897, č. 6424, s. 2. 
ohňostroj. " Český tisk její slova potvrzoval. „Hudba Smetanova shledána čarovnou a veskrze originální i pronášeno ode všech prítomných jednomyslné přání, aby dílo Smetanovo záhy bylo provedeno v Paříži. Kněžna Metternich-Sándorová, zastupující české Národní divadlo, podala paní Maurelové, které přsisluši největši zásluha o uskutečnění myšlenky kněžny Metternichové, nádhernou kytici orchideovou, jižz zaslalo ředitelství Národního divadla z Prahy [...]. Na červenobílých stuhách byl zlatem vyšitý český nápis: ,Pod dechem jara a čarovnýma rukama žen rozkvétaji květy a umění. - České Národni divadlo v Praze. Konce stuh byly vyšity motivy českého národního vyšivání ve zlatě a granátech. V sále vystaveny byly originálni kroje plzeňské, jichž v opeře se uživá. Celý večer zpưsobil dojem neobyčejný a hluboký. Jest naděje,

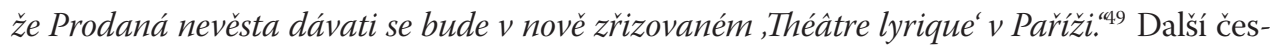
ký zpravodaj si posteskl, že umělci v doručených kostýmech nevystupovali. „Francouzům to snad připadalo jinak, ale v mých očich se prepodivně vyjímali i ta Mařenka v hluboce vystřižené nádherné róbě s velkou diamantovou hvězdou na prsou, i ten Kecal a Jeník v bezvadných černých fracích a bílých kravatách [...].50 Francouzský překlad byl hodnocen jako plynulý, ale zbaven českého rázu. „Jest to patrně překlad z němčiny, odvar tedy z odvaru a tu arci se všecko češství musilo dávno z něho vykouřiti. ${ }^{\text {‘1 }}$ Francouzský tisk výkony umělců chválil, zejména duet v podání E. Engela a hraběnky Maupeouové a duet pánů Carbonna a Maurela, a doufal, že brzy v Paříži zazní celé dílo. ${ }^{52}$ Začátkem října se mělo uskutečnit znovu v salonu Maurelových i druhé představení fragmentární podoby Prodané nevěsty. ${ }^{53}$ „V Pařiži ted všichni po Smetanovi šilí, a Maurelovi byli požádáni, aby na podzim uspořádali ještě jedno smetanovské soirée. ${ }^{54}$ Následně Metternichová požádala Blondela o kompletní překlad opery. Praktický krok k tomu, aby byla Smetanova opera kompletně provedena na některém z pařížských jevišt', to ale nepřineslo. Podle novinářů se to ale dalo čekat - i když se Smetanův večer „v každém ohledu skvostně vydařil, [...] dotýká se jen jedné části oné elegantní, salonní Pařiže, kdežto vlastni hudebni a divadelní kruhy tím nebyly zasaženy a velká veřejnost vi̊bec o ničem ani nezvěděla. Bude tedy třeba ještě dalšich pokusův aneb energické síly, která

48) „Es war glänzend und Smetana hat weher Triumphe gefeiert. Die 7 Piècen aus der ,Prodana nevesta' sind acclamirt worden. Herr Georges Vanor - ein ,conférencier' wie sie hier zu Lande existieren, hat in kurzen Worten die Bedeutung Smetana's geschildert [...] Ihr schönes Bouquet lag auf dem Clavier. Es ist wunderbar frisch angelangt und nahm sich mit den prachtvollen Schleifen sehr gut aus. Maurel hat sich selbst übertroffen und wurde mit Beifall überschüttet. Vortrefflich war Herr Carbonne und das Duo zwischen ihm und Frl. Leclerc (beide von der Komischen Oper) zündete. Es ist das Duo zwischen Hanns und Marie im letzten Akt. Doch nichts konnte das Duo Kecal's und Hanns übertreffen: Sie hat Dukaten aus dem 2ten Akt welches als SchlußFeuerwerk." Metternichová Šubertovi, dopis z 20. 6. 1897, Paříz. PNP LA, fond F. A. Šubert.

49) Národní listy, roč. 37, 21. 6. 1897, č. 170, s. 3.

50) XYZ [?]: Smetanův večirek u pana Maurela, Národní listy, roč. 37, 25. 6. 1897, č. 174, s. 1 (dále XYZ).

51) Tamtéž.

52) Le Figaro, roč. 43, 20. 6. 1897, č. 171, s. 2.

53) Gil Blas, roč. 19, 23. 6. 1897, č. 6428, s. [2].

54) „In Paris schwärmt nun alles für Smetana und sind Maurel's gebeten worden im Herbste noch eine Smetana Soirée zu veranstalten!" Metternichová Šubertovi, dopis z 28. 6. 1897, Mattstall. PNP LA, fond F. A. Šubert. 
by provozování Smetanovy opery na veřejném jevišti na vzdor a naproti všemu prosadila." ${ }^{\text {" n }}$ Prosazení Prodané nevěsty v Paříži se opět vzdalovalo.

\section{Z korespondence překladatele Raoula Blondela a Pauliny Metternichové}

Další Metternichové neutuchající úsilí dokládá její korespondence s Raoulem Blondelem. „Loni jsem viděla pana Alberta Carrého ${ }^{56}$ a hovořila s ním o Prodané nevěstè. Jak jsem očekávala, byl velmi rezervovaný a zdálo se mi, že Smetanu považuje za ,bezcenného. [...] požádám W... [Weinbergera] o jeho podminky. Je to nejzvláštnějši vydavatel, se kterým jsem se dosud setkala. Zabraňuje, aby díla, která zastupuje, byla uváděna! [...] Samozřejmè by byl Maurel pro roli Kecala úžasnou volbou; ale protože pan Carré nechce Smetanu a Maurel je angažován v Komické opeře, musíme se bohužel smírit s tím, že ho v nejbližšich letech vytvorit tuto krásnou roli neuvidime. Mám takovou představu, že by Prodaná nevěsta mohla být provedena jednou či dvakrát společností Société des Grandes Auditions Musicales, mluvila jsem o tom s hraběnkou Greffulheovou. Nemohl byste, jen tak mimochodem, o tom promluvit s panem Lamoureuxem? ${ }^{57}$ Zdá se mi, že tento činorodý hudebník je jediný, kdo by mohl tento podnik uskutečnit. ${ }^{58}$ Blondelova odpověd’ přinášela další zjištění. „Včera jsem konečně viděl v Opéra-Comique ředitele Carrého a predal mu informace z Vašich dopisů. Byl velmi milý, stejně jako pan Messager, ${ }^{59}$ hudební ředitel, který byl u toho. Ale oba dva mi řekli, že náklady Komické opery neumožňui uvést více než jedno nové zahraniční dilo ročnè. Letos je to opera Jeníček a Mařenka a př́ští rok Komedianti. Také se mnou hovořil o námètu Prodané nevěsty, který mu připadá príliš lokální, než aby zaujal jejich publikum. Výhrady má k postavě Koktavého [Vaška], která mu pripadá nemožná, a role Kecala je podle něj ve Francii těžko pochopitelná. Souhlasí s tím, že hudba je okouzlujicí, protože dílo slyšel dvakrát ve Vídni.

55) XYZ, op. cit. v pozn. 50.

56) Albert Carré (1852-1938), francouzský herec, režisér, dramatik, libretista a divadelní režisér. V letech 1898-1913 a 1918-1925 ředitel pařížské Opéra-Comique. Předtím ředitel Théâtre du Vaudeville.

57) Charles Lamoureux (1834-1899), francouzský dirigent a houslista. V roce 1881 založil významný symfonický Orchestre Lamoureux, který byl přidružený k Théâtre des Champs-Élysées. Orchestr byl založen jako Société des Nouveaux-Concerts za účelem propagace soudobé hudby, zejména děl Richarda Wagnera. Pod Lamoureauxovým vedením se např. uskutečnila pařǐžská premiéra Tristana a Isoldy (Nouveau Théâtre, 1899). Poté se orchestr specializoval na francouzskou hudbu, v premiére uvedl díla Maurice Ravela, Gabriela Fauré nebo Clauda Debussyho.

58) „J'ai vu M. Albert Carré l’année dernière pour lui parler de la Fiancée vendue. Comme je m’y attendais, il s'est montré d'une réserve extrême et m'a paru traiter Smetana comme une ,non-valeur'. [...] je vais faire demander à W... ses conditions. C'est l'éditeur le plus curieux qu'il m'ait été donné de rencontrer dans toute mon existence. Il empêche que les ouvrages qu'il a acquis soient représentés! [...] Évidemment Maurel serait merveilleux dans le rôle de Keçal; mais puisque M. Carré ne veut pas de Smetana et que Maurel est engagé l’Opéra-Comique, il faut bien renoncer à lui voir créer ce beau rôle d’ici à quelques années. J’ai idée que la Fiancée vendue pourrait être représentée une fois ou l'autre par la Société des Grandes Auditions Musicales et j'en ai dit un mot à Madame la comtesse Greffulhe. Ne pourriez-vous pas, une fois en passant, en parler à M. Lamoureux? Il me semble que ce musicien entreprenant serait le seul qui pourrait mener à bonne fin l'enfreprise en question." Metternichová Blondelovi, dopis z 3. 11. 1899, Vídeň. In: BRUNEL, Raoul [BLONDEL]: Souvenirs à propos de „la Fiancée vendue“, Le Ménestrel, roč. 90, 26. 10. 1926, č. 43, s. 443.

59) André Messager (1853-1929), francouzský skladatel, dirigent a první kapelník Komické opery. 

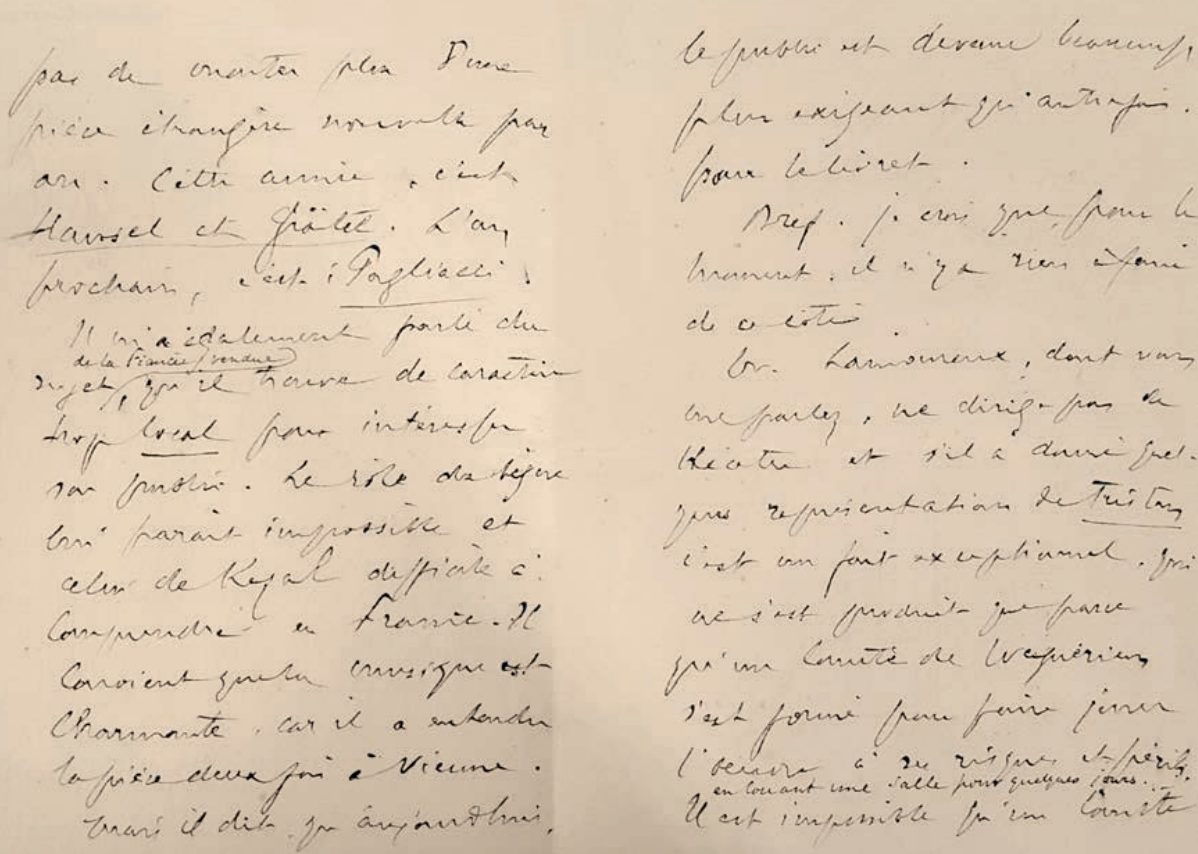

Raoul Blondel: letter to Princess Pauline von Metternich /

Raoul Blondel: dopis kněžně Paulině Metternichové

Autograph, Paris, 20 Nov. 1899 / Autograf, Paříž, 20. 11. 1899

NM-MBS A 129

Podle něj je ale dnes obecenstvo, pokud jde o libreto, mnohem náročnější než dřiv."60 Protože ráz Smetanovy komické opery vylučoval její uvedení v Opéra Garnier, nezbývalo než najít jinou operní scénu. $V$ úvahu stále více připadalo nově vzniklé divadlo Théâtre lyrique de la Renaissance. V prosinci 1899 Blondel oznámil Metternichové, že Théâtre lyrique s hudebním ředitelem Danbém ${ }^{61}$ vážně uvažuje o uvedení Prodané nevěsty ${ }^{62}$ Metternichová Šuberta ujištovala - „ohledně představení v Pařiži se nevzdávám a snažím se pro ně získat Lamoureuxa. [...] Dr. Blondel, horlivý podporovatel Smetanovy hudby, mi znovu psal, aby mi

60) „J'ai enfin vu hier M. Carré à l'opera Comique, et je lui ai dit tout ce que me disaient vos lettres. Il a été très aimable ainsi que $\mathrm{M}$. Messager, le chef de la musique, qui était présent. Mais tous deux m'ont dit que le cahier des charges de l'opéra Comique ne permettaient pas de monter plus d'une pièce étrangère nouvelle par an. Cette année, c'est Hansel et Grötel. L’an prochain, c'est i Pagliacci. Il m’a également parlé du sujet de la Fiancée vendue, qu'il trouve de caractère trop local pour intéreser son public. Le rôle du bègue lui parait impossible et celui de Kezal difficile à comprendre en France. Il convient que la musique est charmante, car il a entendu la pièce deux fois à Vienne. Mais il dit qu'aujourdhui le public est devenu beaucoup plus exigeant qu’autrefois pour le livret." Blondel Metternichové, dopis z 20. 11. 1899, [Paříž]. NM-MBS, fond Nenotové rukopisy a tisky, A 129.

61) Jules Danbé (1840-1905), francouzský houslista, skladatel, operní dirigent a první kapelník Théâtre lyrique de la Renaissance.

62) Blondel Metternichové, dopis z 24. 12. 1899, Paříž. NM-MBS, fond Nenotové rukopisy a tisky, A 130. 
řekl, že ohlednè umožnění představení, Prodané nevěsty' mluvil s ředitelstvím nového operního divadla. Pánové se nezdaji být neochotní, ale nyní to opèt závisí na panu Weinbergerovi, protože mladá společnost nedisponuje velkými finančními prostředky, a proto by vydavatel nemèl mit přehnané nároky!"63

V lednu 1900 se zdálo, že se vedení Théâtre lyrique de la Renaissance již definitivně rozhodlo. Divadlu ale byla odmítnuta subvence, o kterou žádalo. Danbé sdělil Blondelovi jejich nové podmínky: pokud divadlo zajistí dílu dvacet představení, bude naopak divadlu garantován př́ijem 3500 franků za každé představení prostřednictvím 10000 frankủ, které budou složeny do některé banky, aby př́padně kryly divadlu výlohy. Pokud se během produkce na požadovaný přijem dosáhne, bude celý složený obnos vrácen, pokud ne, banka jej divadlu z depozitu vyplatí. Divadlo se domnívalo, že jsou jeho podmínky oprávněné, protože př́ijem za jeden večer obyčejně činil v průměru 4000 (někdy až 9000) franků. Tvrdilo, že se tedy o žádné riziko nejedná a že záruku požaduje jen proto, aby dokázalo vládě, že se bez přidělení subvence neobejde. ${ }^{64} \mathrm{~A}$ tak Šubert v Praze spolu s Družstvem Národního divadla, ${ }^{65}$ intendantem Národního divadla Josefem Heroldem, prezidentem České akademie Josefem Hlávkou, knížetem Lobkovicem a Františkem L. Riegerem inicioval v tisku výzvu „Pro Smetanovu ,Prodanou nevěstu“ $\mathrm{k}$ veřejné finanční sbírce, která měla umožnit uvedení opery v Pařiži během Světové výstavy. Výzva, kterou podepsaly osobnosti i instituce, vyvolala u veřejnosti smíšené pocity. Někteří byli ochotni do sbírky přispět, jiným se to zdálo vůči Smetanovu dílu nedůstojné. Časopis Dalibor, v němž byla výzva otištěna, uveřejnil ostrou reakci: „dilo Bedřicha Smetany nepotřebuje [...] protekce a doprošování se. Stojí snad Smetana niž než Gounod, Verdi, Wagner a ostatní svètoví skladatelé? [...] Máme za to, že úspěch dokonalý může býti dosažen, budou-li prátelé Francouzi dávat, Prodanou nevěstu, protože je dílem geniálního skladatele, ale ne proto, že se nato Češi složili. [...] můžeme klidně ještě počkati do té doby, kdy nauči se prátelé Francouzi tolik geografii, aby věděli, že Praha neleži v Uhrách, aby poznali, že, byt i malým prèece jen jsme vysoko kulturnè vyspělým národem, v umèní, a zvláště hudebním, jedním z prvých."46 Tento odmítavý postoj ještě podpořila poplašná zpráva o tom, že Prodaná nevěsta má být uvedena v divadle Théâtre lyrique v rue Vivienne, v zastrčeném divadélku, které je „více koncertní než divadelní salon, asi o 150 sedadlech, bez mista pro orchestr, který se v něm nedá umistiti, leda by se směstnal v prostoře, kterou tam zaujimá koncertní klavír. [...] Chtíti tam uvésti nejspanilejší kvèt české hudby, sličnou dceru musy neštastného Smetany, je blasfemií, ironii!! Tam zprofanisuje se ,Prodaná

63) ,ich wegen einer Aufführung in Paris nicht nachlasse und Lamoureux dafür zu interessieren trachte. [...] Dr. Blondel der eifrige Förderer der Musik Smetana's hat mir wieder geschrieben um mir zu sagen daß er mit dem Direktorium des neuen lyrischen Theaters Rücksprache getroffen habe wegen der Ermöglichung einer Aufführung der, Verkauften Braut'. Die Herren scheinen nicht abgeneigt zu sein es hängt aber jetzt wieder sich von Herrn Weinberger ab da das junge Unternehmen nicht über große Fonds verfügt und daher der Verleger keine übertriebenen Ansprüche fallen sollte!" Metternichová Šubertovi, dopis z 9. 11. 1899, Drážd'any. PNP LA, fond F. A. Šubert.

64) Blondel Metternichové, dopis z 20. 3. 1900, [Pařiž]. NM-MBS, fond Nenotové rukopisy a tisky, A 131.

65) Výbor Družstva Národního divadla se zaručil př́spěvkem 2000 korun.

66) Dalibor, roč. 22, 14. 4. 1900, č. 17-18, s. 141. 
nevěsta'za naše penize. [...] odsuzujeme provedení,Prodané nevěsty'za 10.000 našich franků $v$ nedůstojném ovzduší!!"67 Nedůvěra panovala vůči pařížskému nastudování, které za české peníze prý udělá z „Vaška blbého kretina“ a z komediantské scény „surově hloupou cirkusní praskavku“. ${ }^{68}$ Rozdmýchané vášně klidnil mimo jiné také nový ředitel Národního divadla Gustav Schmoranz, ${ }^{69}$ který na pravou míru uvedl, že došlo k záměně dvou divadel a že se správně jedná o Théâtre lyrique de la Renaissance, které je jedno nejelegantnějších pařížských divadel a má kapacitu kolem 1000 míst. $^{70}$

Složitou situaci kolem pařížských divadel Metternichové vysvětloval Blondel. „Nikdy bych nenechal provést Prodanou nevěstu v sále se 190 misty s 12 hudebniky. [...] v malém divadle v ulici Vivienne se hraji staré komické opery, které většina Pařržzanu ani nezná. Pravé théâtre lyrique sídlilo v divadelním sále della Renaissance až do minulého března. Bylo to tam pŕiliš malé, $i$ když tam je 800 až 900 mist. Ředitel udělal dobrý obchod, když svůj sál pronajal velice draze operetnímu souboru během Světové výstavy a když své divadlo přesunul do divadla Château-d'Eau, kde je 1800 míst. Tam by se mèla hrát Prodaná nevěsta. Ve chvíli, kdy bylo oznámeno, že divadlo konči a otevře znovu až v zárí, byli už umělci vybráni. Není třeba toho príliš litovat: $v$ tomto sále, který je príliš vzdálený [od centra], by tržby byly minimální. Lidem by to pripadalo moc daleko. Ostatně už začíná být jasné, že divadla chybují, když počitají s vysokými tržbami během tohoto léta. Obecenstvo dává totiž prednost výstavě [Světová výstava], která se koná během dne a má spoustu atrakcí. Pan Milliaud ${ }^{11}$ mi slibil, že uvede Prodanou nevěstu na začátku sezóny v pưvodním sále, kam se od zář́ vrací."72 Théâtre lyrique de la Renaissance se však ocitlo ve vážných finančních potížích a nakonec zbankrotovalo. Naštěstí včas pro štědré donátory z Prahy, kteří tak v podniku neutopili své peníze. Jednání byla přerušena také kvůli změně ve vedení Národního divadla. „Neztrácím naději. Budu trpělivě

67) „Prodaná nevěsta“ do Paříže, Dalibor, roč. 22, 21. 4. 1900, č. 19, s. 145-146.

68) Tamtéž.

69) Do vedení Národního divadla nastoupil Gustav Schmoranz v roce 1900.

70) G. S. [SCHMORANZ, Gustav]: K vypravení „Prodané nevěsty“ do Pařiže, Národní listy, roč. 40, 1. 5. 1900, č. 119, s. 2 [4].

71) Bratři Milliaudové byli od března 1899 do března 1900 řediteli Théâtre lyrique de la Renaissance.

72) „Jamais je n’aurais peu penser à faire exécuter la fiancée vendue dans une salle de 190 places avec 12 musiciens: petit thèâtre de la rue Vivienne où l'on joue de vieux opéras comiques et que la plupart des Parisiens ne connaissent même pas. Le thèâtre lyrique véritable était installé dans la salle du thèâtre dela Renaissance jusqu'au mais dernier. Il s'y est trouvé trop à l'étroit bien qu'il y eut 800 à 900 places. Le directeur a cru faire une belle affaire en louant sa salle très cher à une troupe d'opèrette pendant l'Exposition et en transportant son thèâtre dans la salle du Chateau d'Eau, qui renferme 1800 places. C'est là qu'on devait joue la Fiancée Vendue. Les artistes étaient déjà choisis, quand on vient d'annoncer que le thèâtre fermait ses portes pour ne rouvrir qu'en septembre. Il ne faut pas trop le déplorer: dans cette salle trop lointaine les recettes étaient nulles: les gens chic trouvaient cela trop loin. D'ailleurs on commence à comprendre que les thèâtres ont eu tort de compter sur de grosses recettes pendant cet été. Le public préfére aller à l’Exposition, qui est avant le soir et où il y a une foule d'attractions. M. Milliaud n'a promis qu'il monterait la Fiancée dès la réouverture, dans son ancienne salle, dont il reprendra possession en septembre." Blondel Metternichové, dopis z 26. 4. 1900, Pařižz. NM-MBS, fond Nenotové rukopisy a tisky, A 133. 
čekat na novou scénu, která jednoho dne bude s provedením Prodané nevěsty souhlasit. [...] Bohužel náš ředitel, pan Šubert, byl nahrazen mladým Čechem, který ale za moc nestoji."73

V souvislosti s vydáním Ritterovy francouzské knihy o Bedřichu Smetanovi ${ }^{74}$ se v tisku znovu začaly objevovat spekulace, že by se Prodaná nevěsta měla brzy objevit na jevišti Komické opery. O reálné možnosti Prodanou nevěstu na pařížská pódia aktuálně uvést Rittter však velmi pochyboval. Podle něj je Paříz městem, které se „domnívá býti v čele všeho a jež nesnese myšlenku, že by se mělo po čtyřiceti letech obdivovati dílu, jemuž ostatní Evropa zatím již tleskala, aniž by se prve jeho svoleni byla dovolávala. Naše čtenáre prosíme uctivè, aby nám tuto pessimistickou řeč odpustili! Hudba Smetanova jest z nejkrásnějšich, z nejšlechetnějších, z nejprostších a z nejdi̊stojnèjšich. [...] Třesu se však věru, zda tato hudba Smetanova nebude soběstačností pařížskou nespravedlivě označena za jednu z těch, jež nemohou již nijakého naučení prinésti hudebníkưm a obecenstvu francouzskému.75 Novým impulsem v prosazování Prodané nevěsty na pařížská pódia bylo její uvedení v Bruselu v Divadle de la Monnaie 23. února 1907 v překladu Raoula Blondela. Blondel Metternichové sděloval, že by měl na bruselskou premiéru dorazit také ředitel Carré, který mu dal najevo, že ho dílo velmi zajímá. Blondel mu předal exemplář svého francouzského překladu, který právě vyšel v Lipsku. Vyjádřil naději, že úspěch Prodané nevěsty v Bruselu by snad Carrého k jejímu uvedení v Komické opeře přesvědčil. ${ }^{76}$ Vydání Blondelova překladu bylo ale poznamenáno nevhodnými úpravami i tiskovými chybami. Blondel byl přesvědčen, že opera mohla mít výraznější úspěch, kdyby byla provedena s větší péčí a nadšením. Místo dvou dekorací byla použita pouze jedna - velmi prostá náves uprostřed s kašnou a tekoucí vodou, což bylo extrémně rušivé. Divadlo nahradilo recitativy mluveným slovem, což byla podle Blondela fatální chyba. Užitá próza totiž podtrhla rozdělení opery na jednotlivá čísla, a proto působila ještě o půl století starší. ${ }^{77}$

\section{Cesta k premiéře v Komické opeře v roce 1928}

Další příležitost prosadit Smetanovu operu v Paříži měl krátce před válkou v roce 1913 houslista Jan Kubelík, který do Paříže zavítal, aby tam uspořádal několik koncertů. První z nich se konal v právě dostavěném Théâtre des Champs-Elysées, jehož ředitel Gabriel Astruc ${ }^{78}$ se v roce 1913 chystal uvést italskou operu s Emou Destinnovou a ruský balet. ${ }^{79}$ Kubelík uvedení Smetanovy opery navrhl Astrukovi a ten slíbil věc podpořit v př́padě, že by Kubelík

73) „Je ne perds pas courage. J’attendrai patiemment qu'une nouvelle scène accepte un jour la Fiancée vendue. [...] Hélas ! notre directeur, M. Subert, est remplacé par un ,Jeune Tchèque' qui ne le vaut ni de près ni de loin." Metternichová Blondelovi, dopis z 9. 5. 1900, Vídeň. In: BRUNEL, Raoul [BLONDEL]: Souvenirs à propos de „la Fiancée vendue“, Le Ménestrel, roč. 90, 2. 11. 1926, č. 44, s. 454 (dále BRUNEL).

74) RITTER 1907, op. cit. v pozn. 3.

75) RITTER 1909, op. cit. v pozn. 2, s. 286.

76) Blondel Metternichové, dopis z 18. 2. 1907, Paříz. NM-MBS, fond Nenotové rukopisy a tisky, A 134.

77) BRUNEL, op. cit. v pozn. 73, s. 455.

78) Gabriel Astruc (1864-1938), francouzský novinář, dramatik a impresário, zakladatel a ředitel Théâtre des Champs-Élysées.

79) Právě v Théâtre des Champs-Elysées se 29. 5. 1913 uskutečnila premiéra Svěcení jara Igora Stravinského, provedená Ruským baletem. 


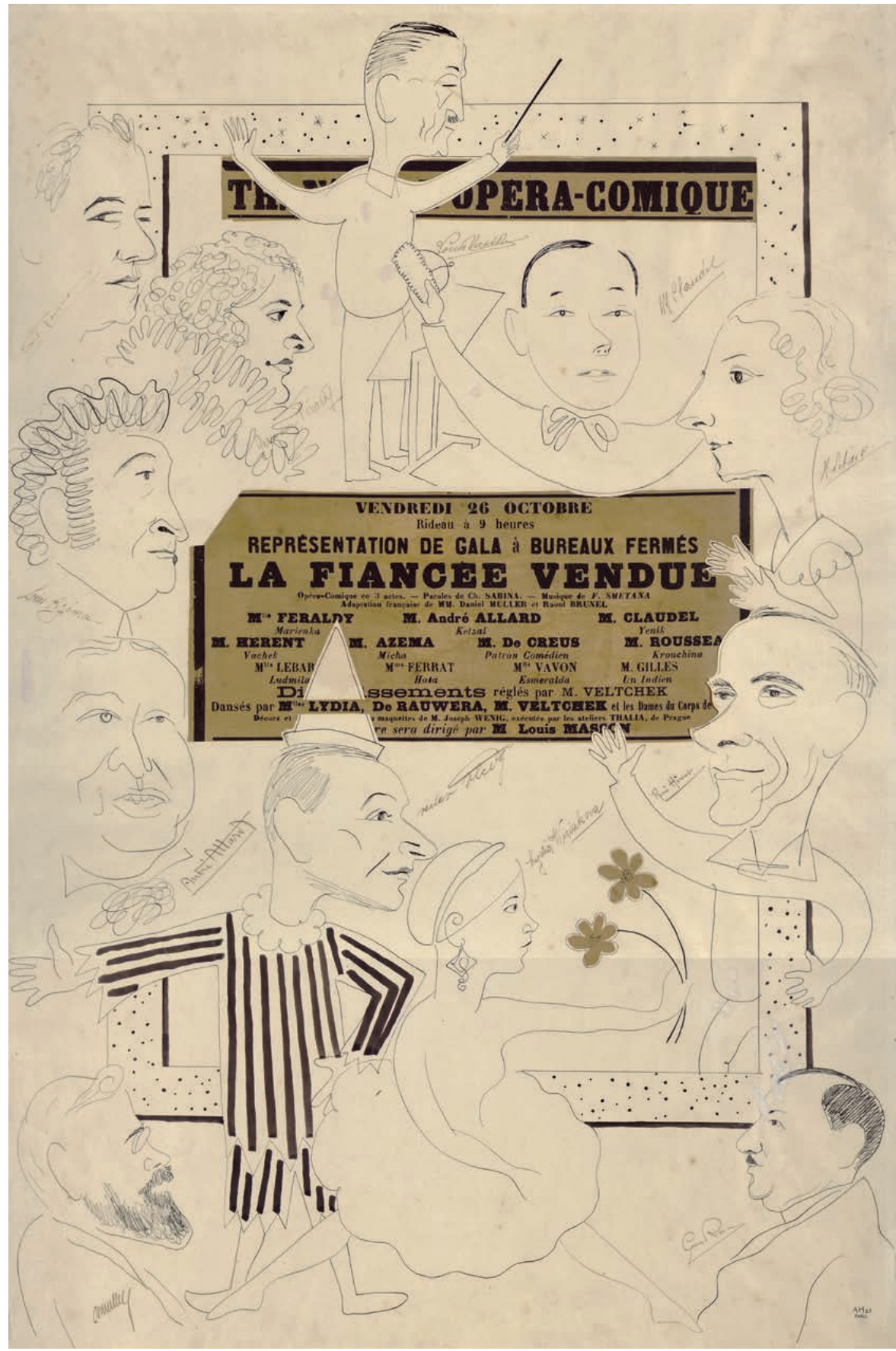

Caricatures of performers and their autographs from a performance of The Bartered Bride I Karikatury interpretů a jejich autogramy z provedení Prodané nevěsty

Drawing by / Kresba Adolf Hoffmeister, Paris / Pař́žz, 1928

NM-MBS M 821 
mezi akty zahrál některé české skladby. Podle Victora Darrase ${ }^{80}$ Astruc telegraficky vyjednával s Národním divadlem. Ředitel Schmoranz žádal garanci 20000 franků za večer. Astruc naopak počítal s deficitem 50000 za cyklus Smetanových oper (Prodaná nevěsta, Dalibor, Hubička a Dvě vdovy). Kubelík, aby zájezd Národního divadla umožnil, byl připraven nejen sám vystoupit, ale i převzít polovinu event. deficitu. Astruc i Schmoranz se nakonec dohodli. Orchestr s českými sólisty, Destinnovou, Mařákem, Burianem, Ludikarem a dalšími, měl řídit Karel Kovařovic. Prodaná nevěsta měla být hrána nejdříve česky a pak francouzskými umělci za spoluúčinkování výše jmenovaných českých pěvců, kteří ovládali francouzštinu. I když zájezd, který byl stanoven na 19. až 24. června 1913, zastřešovala banka Bohemia, kvůli finančním problémům byl na poslední chvíli odložen na podzim 1914. To už ale vypukla válka. ${ }^{81}$

Vznik československého státu v roce 1918 opět posunul otázku uvedení Smetanovy opery v Paříži do popředí. V roce 1925 se do věci zapojil režisér Jaroslav Kvapil, který předal ministru zahraničních věcí velmi podrobně vypracovaný návrh divadelní realizace, včetně technického scénáře pro francouzská představení, a účastnil se prvních jednání s ředitelstvím Komické opery. Novou velkou propagátorkou Prodané nevěsty se stala bývalá operní pěvkyně a manželka československého velvyslance v Pařízi Pavla Osuská (roz. Vachková).

Do žádného jiného města na světě nepronikala Prodaná nevěsta tak těžce jako do Paříže. Ta byla v roce 1928 poslední významnou evropskou metropolí, ve které měla Smetanova opera premiéru. Mezi prvními pokusy o její uvedení a jejím prvním plným provedením uplynulo dlouhých šedesát let, které za přispění řady osobností, jež se hráz neprrístupné Paříže snažily všemožně prolomit, přinesly mnohé naděje následované četnými zklamáními. Cílem na této klikaté cestě se stal až 26. říjen 1928, kdy se k desátému výročí vzniku Československé republiky v pařížské Komické opeře za prrítomnosti francouzského prezidenta Gastona Doumerguea a významných kulturních činitelů, kritiků i umělců podařilo Prodanou nevěs$t u \mathrm{v}$ překladu Daniela Mullera a Raoula Brunela poprvé uvést. Inscenace ve výpravě Josefa Weniga, v režii Georgese Ricoua a pod taktovkou Louise Massona dosáhla patnácti repríz a na repertoáru se objevovala do roku 1932. Ani tato premiéra však Smetanově opeře trvalejší pařížský život nepřinesla.

Adresa: Kateřina Viktorová, Muzeum Bedřicha Smetany, Novotného lávka 1, 11000 Praha 1, Česká republika

E-mail: katerina.viktorova@nm.cz

80) Viluš Crkal (1884-1946), vl. jm. Vilém Antonín Hypolit, po sňatku užíval jméno Victor Darras, politik a publicista.

81) DARRAS, V.: Česká hudba ve Francii prèed válkou: $K$ premiére Prodané nevěsty, Národní listy, roč. 68, 27. 10. 1928, č. 298, s. 1. 